Prepared for the U.S. Department of Energy under Contract DE-AC05-76RL01830

\title{
Laboratory Evaluation of LED T8 Replacement Lamp Products
}

\author{
EE Richman \\ BR Kinzey \\ NJ Miller
}

May 2011

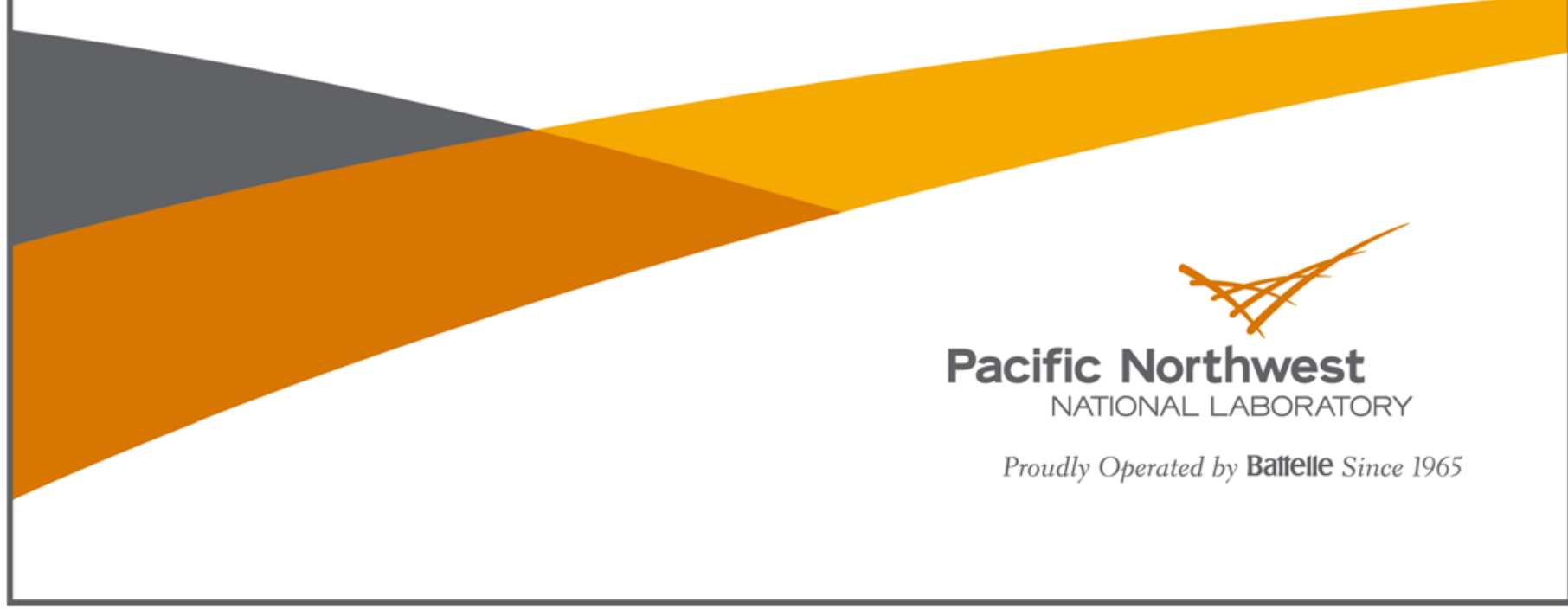




\title{
DISCLAIMER
}

This report was prepared as an account of work sponsored by an agency of the United States Government. Neither the United States Government nor any agency thereof, nor Battelle Memorial Institute, nor any of their employees, makes any warranty, express or implied, or assumes any legal liability or responsibility for the accuracy, completeness, or usefulness of any information, apparatus, product, or process disclosed, or represents that its use would not infringe privately owned rights. Reference herein to any specific commercial product, process, or service by trade name, trademark, manufacturer, or otherwise does not necessarily constitute or imply its endorsement, recommendation, or favoring by the United States Government or any agency thereof, or Battelle Memorial Institute. The views and opinions of authors expressed herein do not necessarily state or reflect those of the United States Government or any agency thereof.

\author{
PACIFIC NORTHWEST NATIONAL LABORATORY \\ operated by \\ BATTELLE \\ for the \\ UNITED STATES DEPARTMENT OF ENERGY \\ under Contract DE-AC05-76RL01830
}

Printed in the United States of America

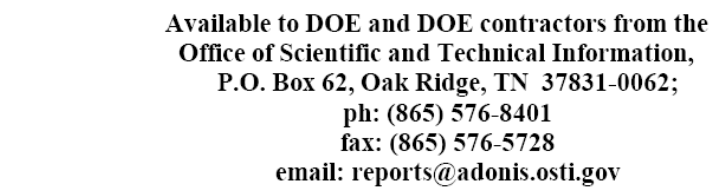

Available to the public from the National Technical Information Service, U.S. Department of Commerce, 5285 Port Royal Rd., Springfield, VA 22161 ph: (800) 553-6847 fax: (703) 605-6900

email: orders@ntis.fedworld.gov

online ordering: http://www.ntis.gov/ordering.htm

Electronic copies of the report are also available from the DOE Solid State Lighting website at http://www1.eere.energy.gov/buildings/ssl/gatewaydemos.html.

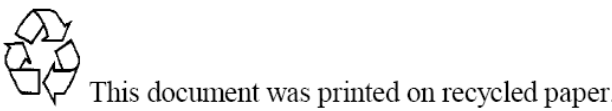




\title{
Laboratory Evaluation of LED T8 Replacement Lamp Products
}

\author{
EE Richman \\ BR Kinzey \\ NJ Miller
}

May 2011

Prepared for

the U.S. Department of Energy

under Contract DE-AC05-76RL01830

Pacific Northwest National Laboratory

Richland, Washington 99352 



\section{Preface}

This document is a report of observations and results obtained from a lighting evaluation project conducted under the U.S. Department of Energy (DOE) GATEWAY Solid-State Lighting Technology Demonstration Program. The program supports investigations of high-performance solid-state lighting (SSL) products in order to develop empirical data and experience with applications of this advanced lighting technology. The GATEWAY program focuses on providing a source of independent, third-party data for use in decision-making by lighting users and professionals; this data should be considered in combination with other information relevant to the particular site and application under examination. Each GATEWAY demonstration compares SSL products against the incumbent technologies used in that location. Depending on available information and circumstances, the SSL product may also be compared to alternate lighting technologies. Though products demonstrated in the GATEWAY program have been prescreened and are often independently tested to verify their actual performance, DOE does not endorse any commercial product or in any way guarantee that users will achieve the same results through use of these products. 


\section{Summary}

Solid-state lighting (SSL) products including light-emitting diodes (LEDs) have been receiving considerable attention because they are thought to offer many potential advantages over conventional lighting technologies. One such advantage is energy savings derived from the lower wattage source. However, energy savings is only one measure of an installation's effectiveness. The quantity and quality of illumination (a potentially broad and complex category) and project cost effectiveness are also important. The U.S. Department of Energy (DOE) GATEWAY Solid-State Lighting Technology Demonstration Program evaluates all aspects of an installation to determine overall suitability of an LED product substitution, including (1) energy savings, (2) illumination quality, and (3) cost-effectiveness.

A primary objective of any lighting project is to satisfy lighting needs. In spaces where lighting levels are higher than recommended or needed, energy savings can almost always be achieved by reducing these levels using new or incumbent technology. However, in spaces where the existing lighting levels are appropriate and should be maintained, any energy savings must instead be achieved by improving the technology or its application. Put another way, maintaining the same level of illumination while using half the electricity is not equivalent to achieving a 50 percent electricity savings by cutting illumination levels by 50 percent. The latter often can be most easily and inexpensively achieved by substituting lower wattage versions of the incumbent technology, or sometimes even by simply "delamping” (i.e., removing some lamps from) existing fixtures.

With standard incumbent technologies like fluorescent, it is relatively easy to incorporate improved efficacy products while maintaining illumination levels due to industry standardization and the resulting interchangeability of components. For newer and different technologies such as LED, however, interchangeability is more challenging.

This study evaluated three LED products designed to directly replace linear fluorescent lamps (most commonly "T8" lamps) in commercial ambient lighting. These three products were among the "best in class" at the time of the study, as identified by DOE's CALiPER testing program. ${ }^{1}$ Many similar products exist in the market and all claim energy savings relative to the targeted incumbent fluorescent systems, but few perform as well as the three selected for this study. The power reductions associated with LED T8 replacement applications are frequently accompanied by significant reductions in lumen output, making them inappropriate as retrofits for the reasons detailed above.

Table ES.1 summarizes the results relevant to each of the criteria for one representative test conducted during the study using a two-lamp prismatic lens fixture. An additional comparison included in the table examines a lower wattage (25W) fluorescent product easily purchased today that provides similar light output to the LED products. Table ES.2 provides reference characteristics for the various products considered in this comparison. In this comparison, all three LED products drew less power than their fluorescent counterparts but, like others of their kind, also provided fewer lumens on the room and work surface grids measured beneath and beside them. The prices of the LED products are such that none pay for themselves when compared to the standard T8 $(735)^{2}$ fluorescent lamp used as the primary baseline in this study.

\footnotetext{
${ }^{1}$ The DOE Commercially Available LED Product Evaluation and Reporting (CALiPER) Program supports testing of a wide array of SSL products available for general illumination. DOE allows its test results to be distributed in the public interest for non-commercial, educational purposes only. http://www1.eere.energy.gov/buildings/ssl/caliper.html

${ }^{2}$ The designation "735" denotes that the lamp has a color rendering index in the range of 70-79 and that the correlated color temperature is a nominal $3500 \mathrm{~K}$. Note that 735 lamps are being phased out by Federal efficiency
} 
Table ES.1 Summary Comparison Results - Two-Lamp Prismatic Lens Application

\begin{tabular}{lcccccc}
\hline \multicolumn{1}{c}{ Product } & $\begin{array}{c}\text { Price per } \\
\text { Lamp } \\
(\$)\end{array}$ & $\begin{array}{c}\text { Measured } \\
\text { Power } \\
\text { (watts) }\end{array}$ & $\begin{array}{c}\text { Avg Horiz* } \\
\text { Workplane } \\
\text { Illuminance (fc) }\end{array}$ & $\begin{array}{c}\text { Avg Vert* } \\
\text { Illuminance } \\
(\mathrm{fc})\end{array}$ & $\begin{array}{c}\text { Life Cycle } \\
\text { Cost } \\
(\$ 2011)\end{array}$ & $\begin{array}{c}\text { Payback } \\
\text { (years) }\end{array}$ \\
\hline Baseline T8 (735) FL & 2.00 & 28.5 & 39.1 & 22.2 & 1099 & NA \\
High lumen T8 FL, LBF & 4.55 & 25.0 & 38.3 & 23.3 & 1129 & 17 \\
Obsolete T12 & 1.85 & 38.0 & 36.9 & 22.2 & NA & NA \\
LED 01 & 89.69 & 18.5 & 31.1 & 17.9 & 1517 & $\begin{array}{c}\text { Not } \\
\text { reached }\end{array}$ \\
LED 02 & 63.75 & 17.0 & 28.9 & 16.2 & 1243 & $\begin{array}{c}\text { Not } \\
\text { reached }\end{array}$ \\
LED 03 & 120.00 & 22.0 & 31.2 & 17.5 & 1886 & $\begin{array}{c}\text { Not } \\
\text { reached }\end{array}$ \\
\hline Comparison 25W T8 FL** & 5.50 & NA & $34.6^{* *}$ & $19.6^{* *}$ & 898 & 2 \\
\hline
\end{tabular}

* Performance values in two-lamp prismatic lens fixture shown. Mounting height is $9 \mathrm{ft}$, horizontal workplane located 30 inches above finished floor (AFF), vertical readings shown are an average of readings at $4 \mathrm{ft}, 5 \mathrm{ft}$, and $6 \mathrm{ft}$ AFF.

** Not tested, for comparison only. Illuminance estimates are based on the ratio of T8 (735) rated output to the 25W T8 rated output.

Table ES.2 Reference Product Characteristics

\begin{tabular}{lcccc}
\hline \multicolumn{1}{c}{ Product } & $\begin{array}{c}\text { Mfr Listed } \\
\text { System* } \\
\text { Power (watts) }\end{array}$ & $\begin{array}{c}\text { Mfr Listed Initial } \\
\text { Lumen Output } \\
\text { (lumens) }\end{array}$ & $\begin{array}{c}\text { Mfr Listed } \\
\text { System* Efficacy } \\
\text { (lumens/W) }\end{array}$ & $\begin{array}{c}\text { Measured } \\
\text { System } \\
\text { Efficacy** } \\
\text { (lumens/W) }\end{array}$ \\
\hline Baseline T8 (735) FL, NBF & 28 & 2800 & 90 & NA \\
High lumen T8 FL, LBF & 24 & 3100 & 97 & NA \\
Obsolete T12, NBF & 34 & 2650 & 56 & NA \\
LED 01 & 19 & 1490 & 78 & $97^{* * *}$ \\
LED 02 & 17 & 1343 & 79 & 93 \\
LED 03 & 21.8 & 1590 & 72.9 & 70 \\
Comparison 25W T8 FL, NBF & 25 & 2475 & 101 & NA \\
\hline
\end{tabular}

* System power and efficacy values are taken from the appropriate ballast catalog that represents the complete lamp+ballast operating system. Efficacies shown do not include fixture efficiency.

** Measured efficacy values are from CALiPER testing reports on the same LED products according to the manufacturer's information.

*** CALiPER tested a preceding generation of this product. This earlier generation product corresponds to CALiPER product test $10-18$.

The comparison and reference data confirm that LED T8 replacement products are coming close to competing with typical fluorescent products in terms of raw efficacy. However, in fixture applications ${ }^{3}$ the LED products show mixed results. The data from prismatic and parabolic troffer applications show that the LED products are effective at delivering light out of the fixture. However, in a "basket" fixture, they do not perform as effectively. In all cases, total light output is lower, and therefore the ability to effectively replace incumbent fluorescent installations remains limited.

standards in favor of "800" series lamps, but as of this writing still comprise a major segment of the installed inventory.

${ }^{3}$ See corresponding sections in the document. 
In the many real-world applications where spaces are over-lighted, the lower output of LED replacements can provide appropriate light levels at lower power levels, but the same result can be achieved with lower wattage fluorescent options at much lower cost and higher maintained light levels over the product's lifetime. Cost-effectiveness remains the primary hurdle to LEDs being widely applicable.

Because it is always possible that LED replacement technologies may find specific applications that merit attention, each specific product and application should be considered on its own cost/benefit basis. Wide-scale adoption of LED T8 replacement lamps should not be pursued without such a thorough evaluation, however.

It is worth noting that new approaches and LED product designs are continually emerging. Alternative designs, such as panel-type products and overall troffer replacement systems, may prove more effective in the future than the products tested in this study, which are designed to substitute for fluorescent lamps in existing troffers. None of these alternative whole-luminaire designs were evaluated here, but warrant the same kind of comprehensive evaluation before their widespread adoption is pursued. 


\section{Acknowledgments}

The authors wish to thank the Lighting Design Lab in Seattle, WA for providing the services of their staff and facilities for the laboratory testing. Particular thanks go to Eric Strandberg and Andrea Dahlman of the design lab for assistance in the development of the test system and completion of the testing and data collection. 


\section{Acronyms and Abbreviations}

$\begin{array}{ll}\text { AFF } & \text { above finished floor } \\ \text { BF } & \text { ballast factor } \\ \text { BLCC } & \text { Building Life-Cycle Cost (software) } \\ \text { CALiPER } & \text { Commercially Available LED Product Evaluation and Reporting } \\ \text { CCT } & \text { correlated color temperature } \\ \text { CRI } & \text { color rendering index } \\ \text { DOE } & \text { U.S. Department of Energy } \\ \text { fC } & \text { footcandle(s) } \\ \text { FL } & \text { fluorescent } \\ \text { IES } & \text { Illuminating Engineering Society of North America } \\ \text { K } & \text { kelvin } \\ \text { LED } & \text { light-emitting diode } \\ \text { LDL } & \text { Lighting Design Laboratory } \\ \text { SSL } & \text { solid-state lighting } \\ \text { T8 } & \text { fluorescent tube lamp, 8/8 inch diameter } \\ \text { T12 } & \text { fluorescent tube lamp, 12/8 inch diameter }\end{array}$




\section{Contents}

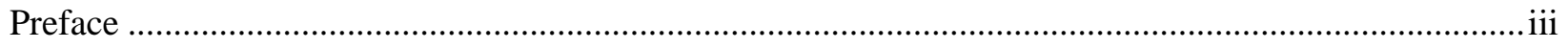

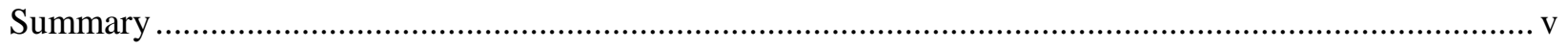

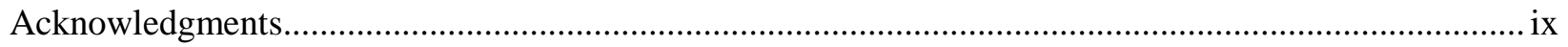

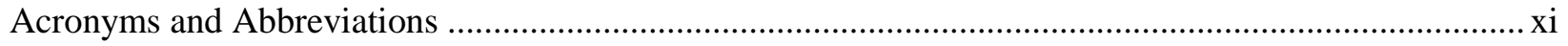

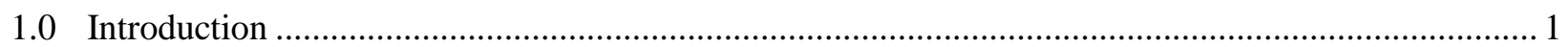

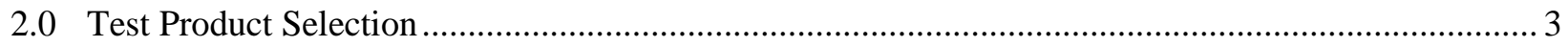

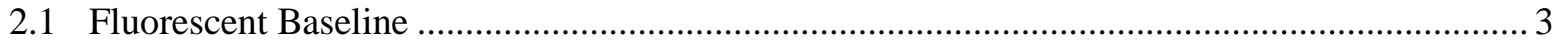

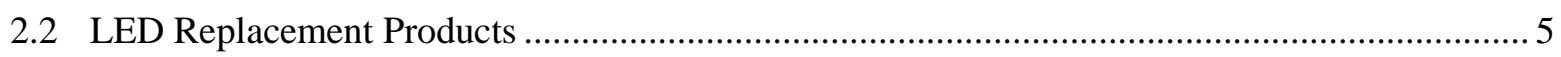

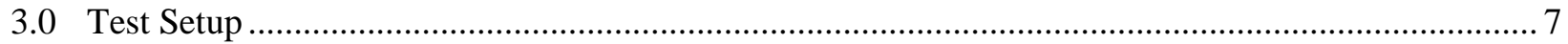

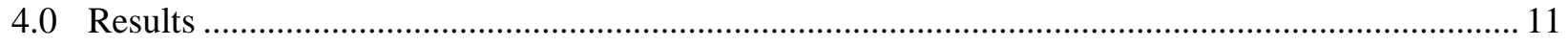

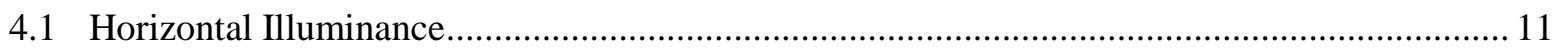

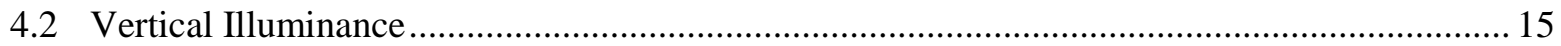

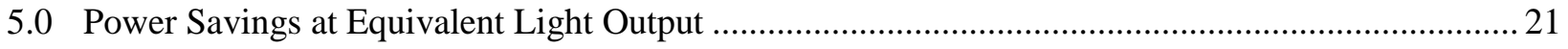

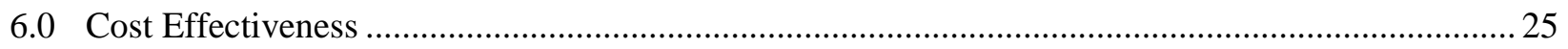

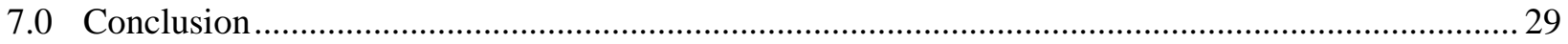

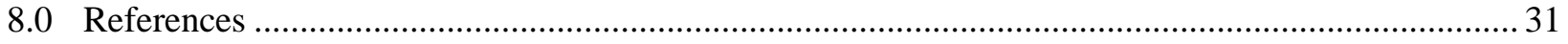

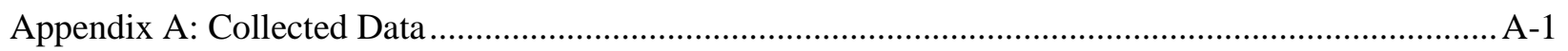




\section{Figures}

Figure 2.1. Section of Troffer with Lens / Acrylic Lens / 76.0 Percent Efficiency

Figure 2.2. Section of Troffer with Parabolic Louver / 18-Cell 3 in. Deep Semi-Specular Louvers / 69.1

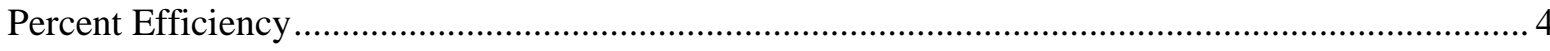

Figure 2.3. Section of Direct/Indirect Toffer (Basket) / 67.8 Percent Efficiency (Two-Lamp) / 63.0

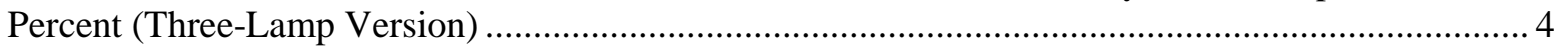

Figure 2.4. Section of "High Performance Lensed” Troffer / Acrylic lens / 80.6 Percent Efficiency ......... 4

Figure 3.1. Test Configuration. One square in the grid represents 1 foot. Measurement points occur at

the center of the shaded horizontal grid squares and at the intersections of the vertical grid lines...... 7

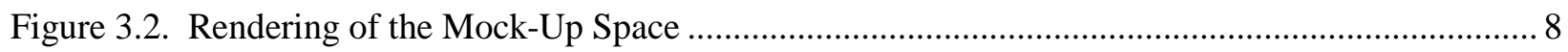

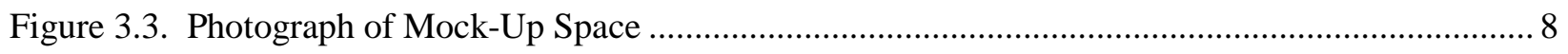

Figure 3.4. Horizontal Illuminance Measurement ......................................................................... 9

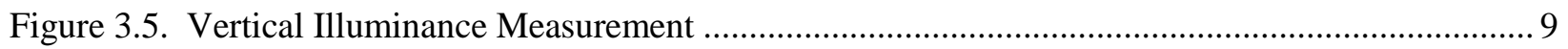

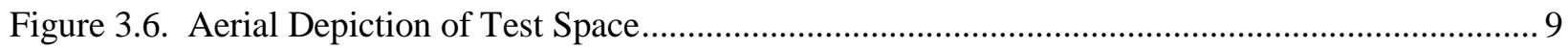

Figure 4.1. LED and Fluorescent Performance in Various Two-Lamp Fixtures, Horizontal Workplane. 12

Figure 4.2. LED and Fluorescent Performance in Various Three-Lamp Fixtures, Horizontal Workplane13

Figure 4.3. LED and Fluorescent Avg-to-Min Ratio for Various Two-Lamp Fixtures, Horizontal Workplane.

Figure 4.4. LED and Fluorescent Avg-to-Min Ratio for Various Three-Lamp Fixtures, Horizontal

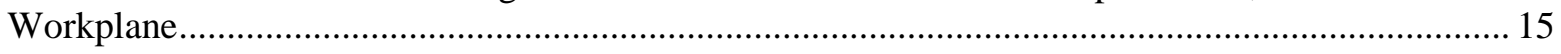

Figure 4.5. LED and Fluorescent Performance in Various Two-Lamp Fixtures, Vertical Plane .............. 16

Figure 4.6. LED and Fluorescent Performance in Various Three-Lamp Fixtures, Vertical Plane ............ 17

Figure 4.7. LED and Fluorescent Avg-to-Min Ratio for Various Two-Lamp Fixtures, Vertical Plane. . 18

Figure 4.8. LED and Fluorescent Avg-to-Min Ratio for Various Three-Lamp Fixtures, Vertical Plane .. 19

Figure 5.1. Percent Savings with Output Normalized to Standard FL T8, Horizontal Workplane ........... 22

Figure 5.2. Percent Savings with Output Normalized to Standard FL T8, Vertical Plane........................ 23

Figure 6.1. Light Level Reduction Over Time Including Lamp Replacement on Failure......................... 28

\section{Tables}

Table ES.1 Summary Comparison Results - Two-Lamp Prismatic Lens Application ..............................vi

Table ES.2 Reference Product Characteristics .......................................................................................... vi

Table 2.1. Fluorescent Lamp Measured Characteristics (per Lamp) ......................................................... 3

Table 2.2. Measured LED Product Characteristics ........................................................................... 5

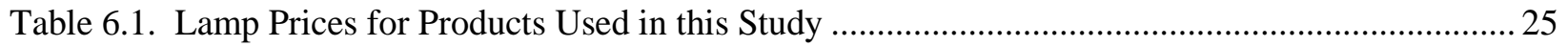

Table 6.2. Total Installation and Lifecycle Costs - T8(735) Baseline .................................................... 26

Table 6.3. Total Installation and Lifecycle Costs - T12 Baseline ......................................................... 27 


\subsection{Introduction}

Lighting accounts for about 38 percent of electricity use in the U.S. commercial sector (EIA 2008). Long hours of operation associated with business operations and a continuous focus on reducing costs over the last several decades have led to the development of lighting products with long lifetimes and low costs to serve the commercial sector. These products also typically exhibit a fairly high degree of lighting efficiency, color quality, and lumen maintenance, specifically in the form of linear fluorescent lamp technology.

Because of linear fluorescent lamp technology's long stature in the market, almost every lighting manufacturer has designed fixtures and systems around it, and most of these systems are interchangeable. For example, fluorescent lamps from different manufacturers can be used at the same time in the same fixture produced by a third manufacturer, driven by a ballast from a fourth manufacturer (though this may result in less-than-optimal performance from the luminaire). As a result, replacement components are often selected based on meeting performance minimums and cost with little need to consider differences between manufacturers.

This sizable and stable market is very attractive to manufacturers of new light-emitting diode (LED) lighting products. Any product that ultimately competes with linear fluorescent technology has tremendous market potential.

The DOE GATEWAY Solid-State Lighting Technology Demonstration Program receives frequent requests from manufacturers, sites, utilities, efficiency organizations, and consultants wanting to demonstrate, evaluate, or promote LED linear T8 replacement products. Unfortunately, many early products suffered from poor performance, high costs, questionable construction, and other weaknesses that precluded DOE interest in further investigating their market readiness. Numerous early products tested under DOE’s Commercially Available LED Product Evaluation and Reporting (CALiPER) Program were clearly shown to have lower performance in one or more aspects compared to the linear fluorescent products they were intended to replace.

However, more recent CALiPER testing has identified products that are beginning to show efficacy performance at levels competitive with linear fluorescent. The variability of conditions among completed or potential real-world installations does not provide a uniform platform for evaluating the product's capabilities. Therefore, a controlled mock-up test was developed to effectively evaluate all capabilities and overall suitability of these products as replacements for T8 systems.

For this project, the GATEWAY program team partnered with the Lighting Design Laboratory (LDL), operated by Seattle City Light, because of their lighting mock-up facility and experience in lighting evaluation. 


\subsection{Test Product Selection}

Today's market has many permutations of both existing fluorescent systems and potential LED replacement products - far too many to test all possible combinations. This project's primary purpose was to examine these products for suitability in mainstream applications. The evaluation was thus designed to involve common fluorescent troffer fixtures with typical, mainstream lamp and ballast options. Multiple LED replacement products were selected to represent the "best in class" at the time of the study, as detailed below.

\subsection{Fluorescent Baseline}

Baseline fluorescent technologies were selected to represent typical office lighting practice for new construction as well as commonly found options for retrofits of older office lighting installations. Lamp and ballast technologies evaluated include:

A. Lamp: Standard T12 (2650 initial lumens, 4200 kelvin (K), 60 color rendering index (CRI)) (SYLVANIA F34CW/SS/ECO) $^{4}$

Ballast: magnetic

B. Lamp: Standard T8 with common lamp series 735 (2800 initial lumens, 3500K, 78 CRI OSRAM SYVLANIA FO32/735/ECO)

Ballast: Instant-start normal ballast factor (BF) (0.88) ballast (OSRAM SYLVANIA QTP 2/3x32T8/UNV ISN-SC)

C. Lamp: "High Performance” T8 enhanced lamp series 835 (3100 initial lumens, 3500K, 85 CRI OSRAM SYLVANIA FO32/835/XPS/ECO3)

Ballast: Instant start low BF (0.78) ballast (OSRAM SYLVANIA QHE 2/3X32T8/UNV-ISL-SC)

Measured power characteristics for each of these fluorescent options are shown in Table 2.1.

Table 2.1. Fluorescent Lamp Measured Characteristics (per Lamp)

\begin{tabular}{lc}
\hline \multicolumn{1}{c}{ Fluorescent Baseline Option } & $\begin{array}{c}\text { Measured Power } \\
\text { (watts) }\end{array}$ \\
\hline A - Standard T12 with magnetic ballast & 38.0 \\
B - Standard T8 (735) with instant start electronic ballast & 28.5 \\
C - High Performance T8 (835) with low BF instant start ballast & 25.0 \\
\hline
\end{tabular}

Three common $2 \mathrm{ft} \times 4 \mathrm{ft}$ fixture types were chosen to represent common practice for most acoustic ceiling tile (grid) applications: prismatic lens (Figure 2.1), parabolic (Figure 2.2), and basket troffer designs (Figure 2.3), each in two-lamp and three-lamp configurations. A fourth fixture type, prismatic high performance (Figure 2.4), was tested in limited two-lamp configurations as the schedule allowed.

\footnotetext{
${ }^{4}$ Many T12 components can no longer be manufactured due to the scheduled phaseout, but were included in the study due to the remaining high inventory of such products in the market.
} 
Note that the fixture efficiencies provided are for reference only as they are based on the omni-directional sources for which they were designed (i.e., linear fluorescent lamps) and will not necessarily provide the same performance with other types of source distribution.

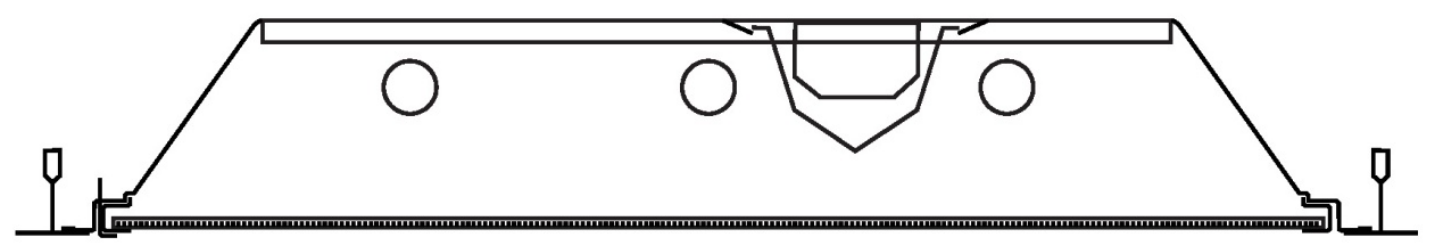

Figure 2.1. Section of Troffer with Lens / Acrylic Lens / 76.0 Percent Efficiency

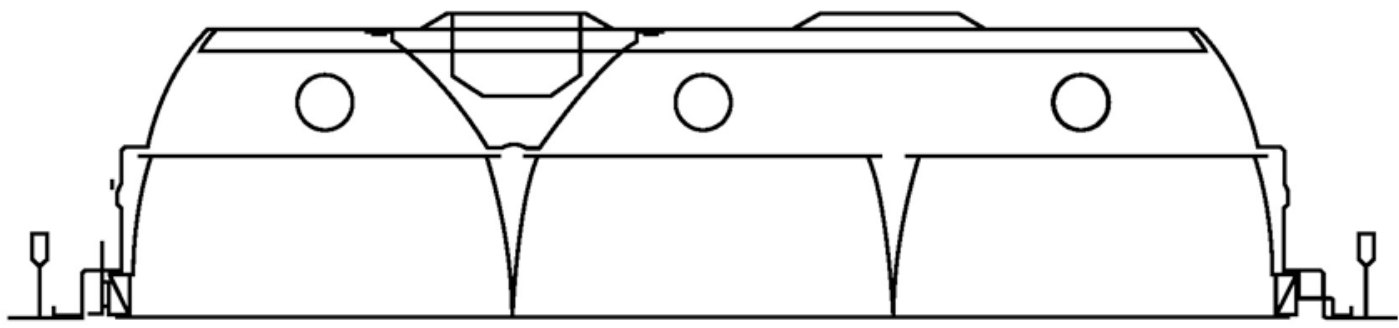

Figure 2.2. Section of Troffer with Parabolic Louver / 18-Cell 3 in. Deep Semi-Specular Louvers / 69.1 Percent Efficiency

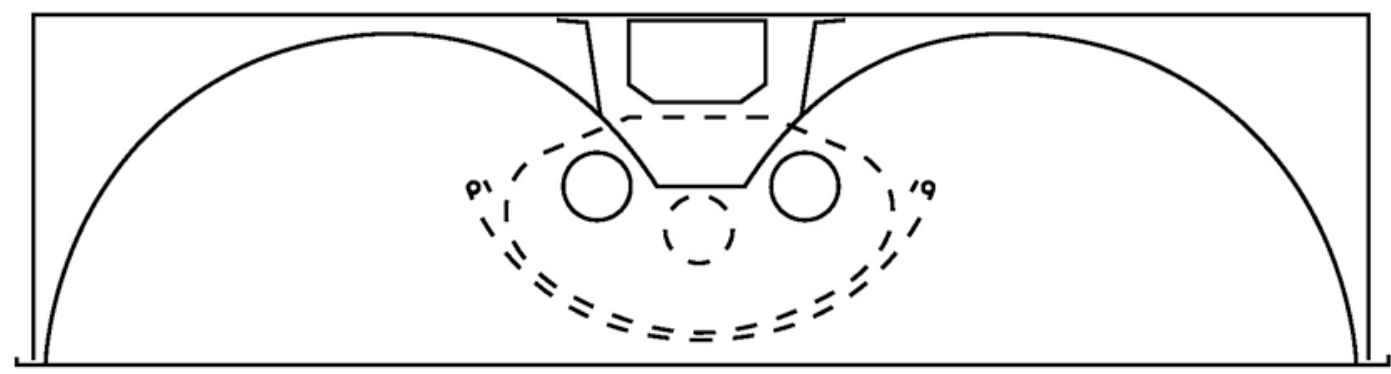

Figure 2.3. Section of Direct/Indirect Toffer (Basket) / 67.8 Percent Efficiency (Two-Lamp) / 63.0 Percent (Three-Lamp Version)

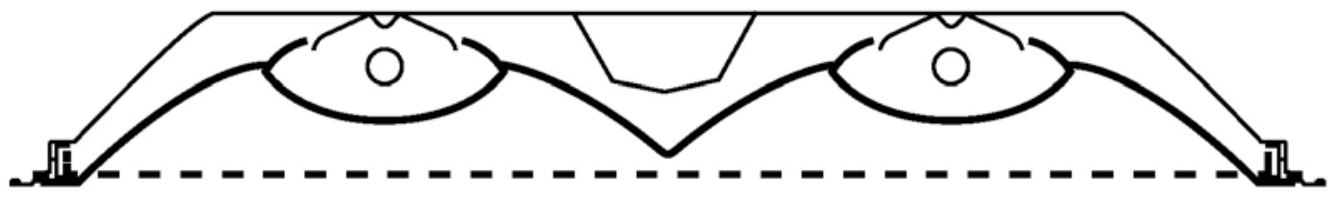

Figure 2.4. Section of "High Performance Lensed” Troffer / Acrylic lens / 80.6 Percent Efficiency 
Although other fluorescent fixture configurations are available, these represent much of the existing U.S. market for typical office type lighting. These are therefore used to establish and support general conclusions about the overall readiness of the replacement technology.

\subsection{LED Replacement Products}

When this study began, the CALiPER Program had tested 17 LED T8 replacement products over 4 years, which as a group represented the range of performance capabilities within this product type. Three products were chosen for this evaluation that were either directly tested by CALiPER or are related to a product tested. The selected products represent three of the top performers among available products based on:

- high efficacy

- high output

- wide distribution. $^{5}$

Table 2.2 presents the performance characteristics for the three LED products selected. Both manufacturer-reported data and CALiPER test data (where available) are included. All LED products evaluated in this study were ordered during September, 2010.

Table 2.2. Measured LED Product Characteristics

\begin{tabular}{|c|c|c|c|c|c|c|}
\hline Product & $\begin{array}{c}\text { Measured } \\
\text { Wattage }\end{array}$ & $\begin{array}{c}\text { Measured } \\
\text { Power Factor } \\
\end{array}$ & $\begin{array}{l}\text { CALiPER } \\
\text { Test No.* } \\
\end{array}$ & $\begin{array}{c}\text { Luminous Flux } \\
\text { (lumens) }^{*}\end{array}$ & $\mathrm{CCT}^{*}$ & CRI* \\
\hline LED01 & $18.5 \mathrm{~W}$ & 0.78 & $(* *)$ & $1453 * *$ & $5638 \mathrm{~K} * *$ & $75.6^{* *}$ \\
\hline LED02 & $17.0 \mathrm{~W}$ & 0.86 & $10-16$ & 1366 & $5394 \mathrm{~K}$ & 77.1 \\
\hline LED03 & $22.0 \mathrm{~W}$ & 0.58 & 09-107 & 1539 & $3548 \mathrm{~K}$ & 72.9 \\
\hline
\end{tabular}

\footnotetext{
${ }^{5}$ Wide distribution is subjective but is used here to denote LED products that provide light distribution across a wider area that contributes to more uniform lighting on both horizontal and vertical surfaces.
} 


\subsection{Test Setup}

Tests were designed to evaluate performance in a setting that represented good lighting practice in expected scenarios for both new installations and retrofits. All tests used a grid of luminaires to provide appropriate light levels in a $16 \mathrm{ft}$ x16 ft room with fixtures centered $4 \mathrm{ft}$ from the walls and $8 \mathrm{ft}$ on center (see Figure 3.1). This setup incorporated spacing, ballast factor, and ceiling height ( $9 \mathrm{ft}$ above finished floor [AFF]) designed to achieve light levels in the $\sim 30$ to $\sim 50$ footcandle (fc) range based on Illuminating Engineering Society of North America (IES) recommendations for office areas and tasks. The respective footcandles reported are as measured in the actual installation.

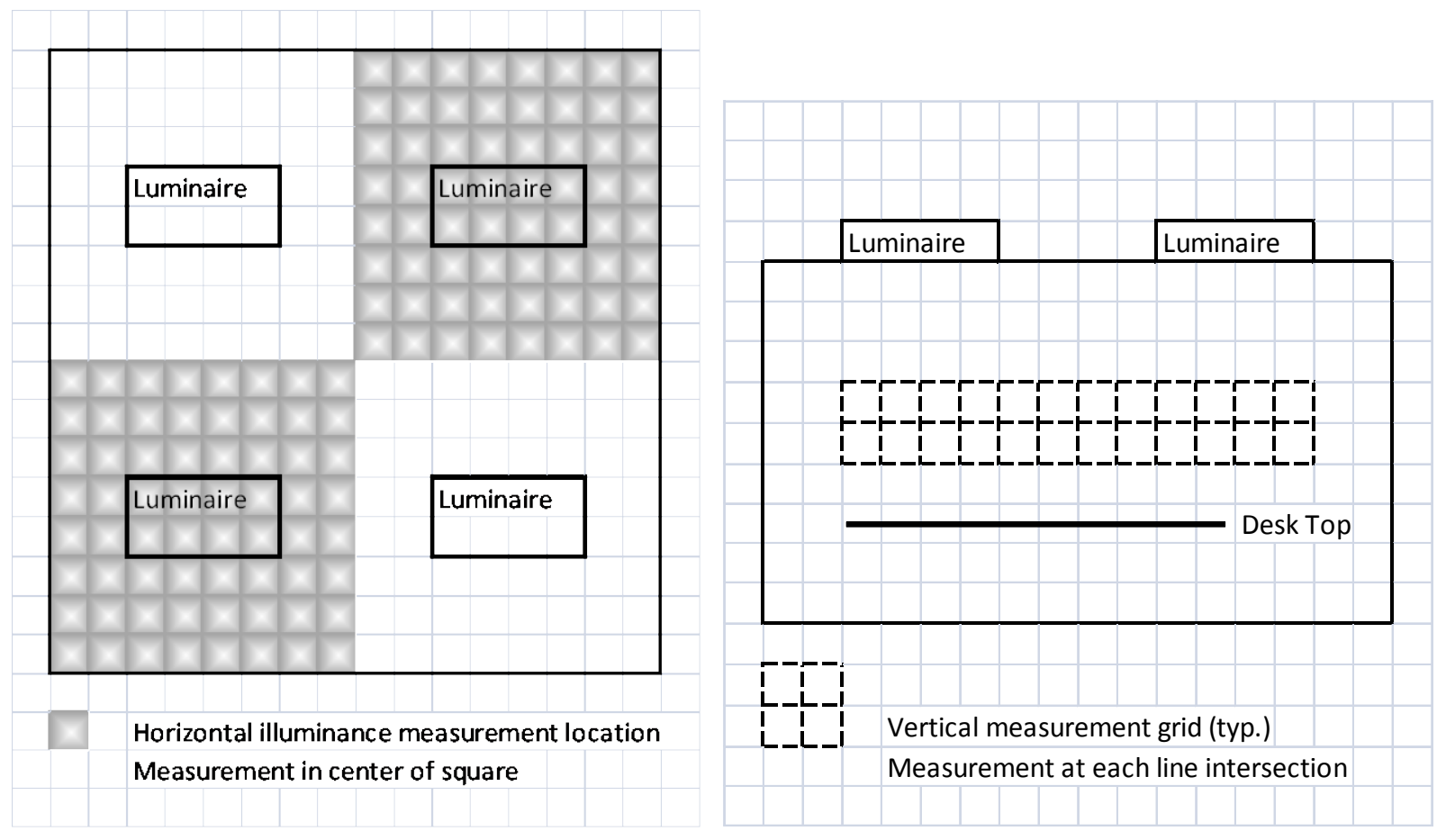

Figure 3.1. Test Configuration. One square in the grid represents 1 foot. Measurement points occur at the center of the shaded horizontal grid squares and at the intersections of the vertical grid lines.

Test parameters:

- Consistent surfaces for measurement—same test area size and reflectance values for all tests

- Ceiling and spacing as defined in test setup

- Same test grids and equipment for all tests, except as noted

Measurements:

1. All fluorescent lamps are to be from the same manufacturer. Pretest all lamps in LDL's linear lamp output test chamber to ensure that all lamps used of each type (T12, T8/735, etc.) are of similar output. Test enough samples to ensure a consistent set of lamps for the tests. Lamps that are tested and considered to have outputs significantly different from the others of their type will not be used. 
2. Horizontal illuminance grid (at $\mathbf{1} \mathbf{f t}$ intervals) at table/desktop (30 inches AFF) covering opposite quadrants of the test space ( 128 measurements with $8 \mathrm{ft}$ by $8 \mathrm{ft}$ luminaire spacing in $16 \mathrm{ft}$ by $16 \mathrm{ft}$ space).

3. Vertical illuminance grid:

a. Aligned along a wall parallel to the long dimension of the luminaire housing. Test at $4 \mathrm{ft}, 5 \mathrm{ft}$, and $6 \mathrm{ft}$ AFF and facing center of test area at $2 \mathrm{ft}$ intervals (21 measurements).

4. Illuminance measurements taken with Minolta T-1 illuminance meter.

5. Power measurements taken with Voltech, PM1000 power analyzer.

Figure 3.2 depicts the overall space. Figure 3.3, Figure 3.4, and Figure 3.5 are photographs of the space, with Figure 3.4 and Figure 3.5 showing the measurement procedure for horizontal and vertical illuminance measurements, respectively. Figure 3.6 is an aerial depiction of the room displaying a typical set of measurements and wall reflectance values. All images are courtesy of Seattle Lighting Design Laboratory.

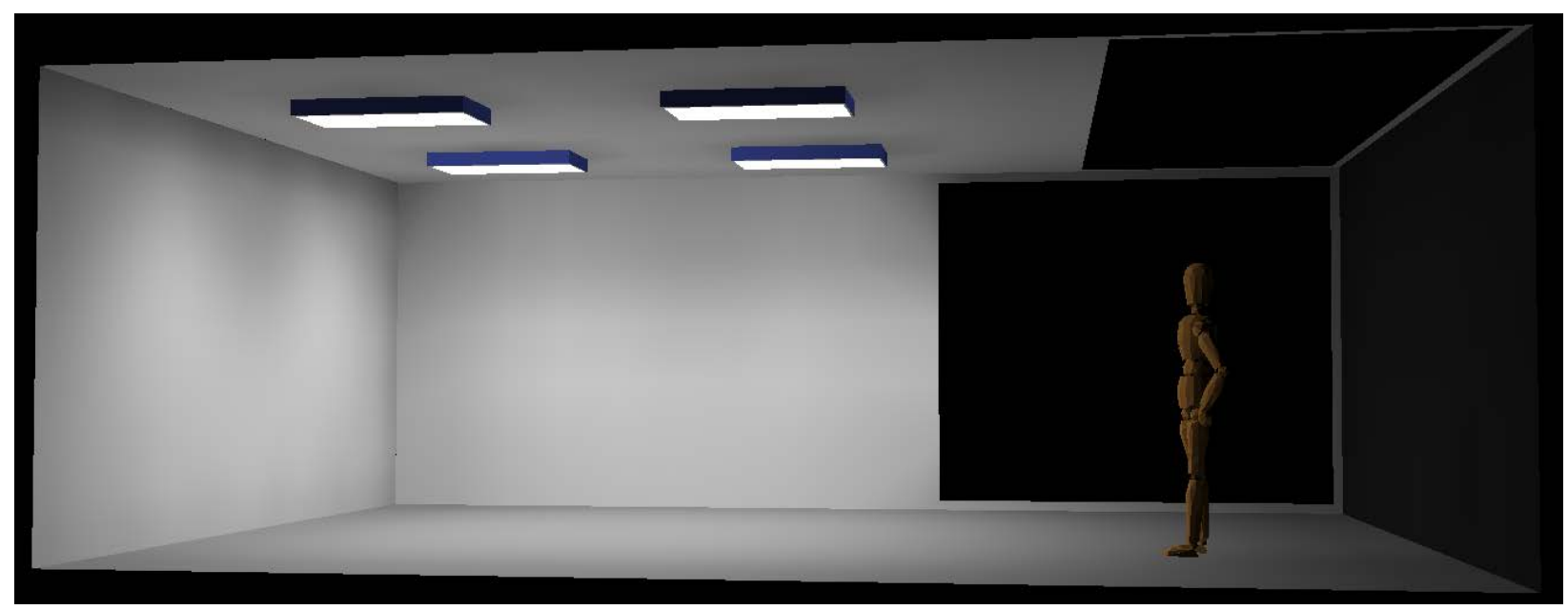

Figure 3.2. Rendering of the Mock-Up Space

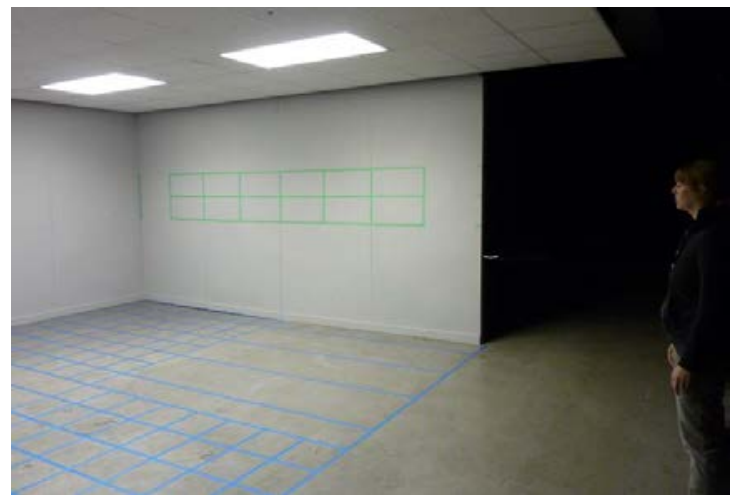

Figure 3.3. Photograph of Mock-Up Space 


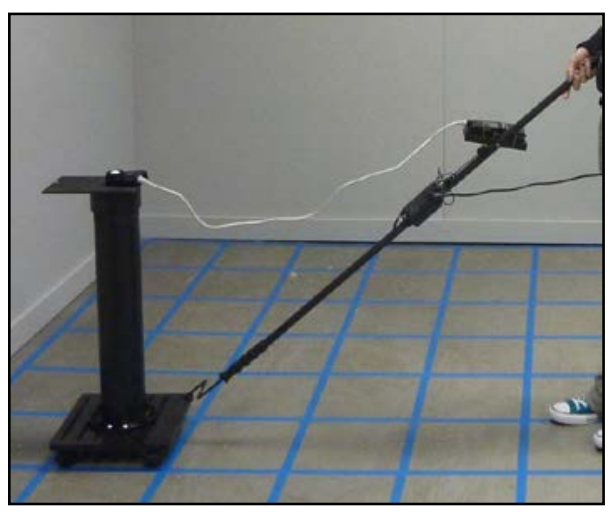

Figure 3.4. Horizontal Illuminance Measurement

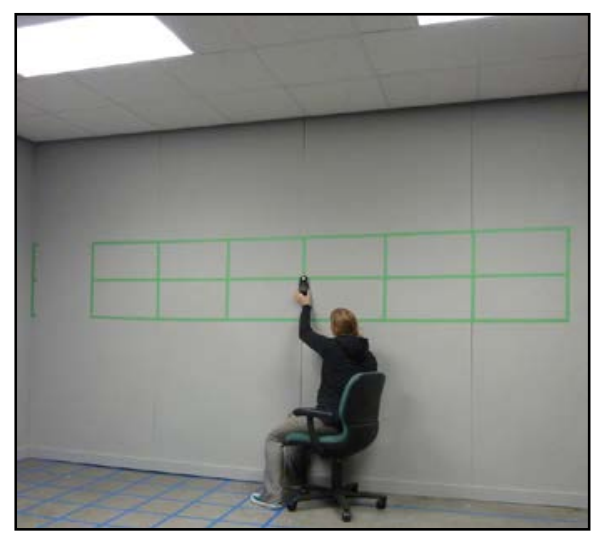

Figure 3.5. Vertical Illuminance Measurement

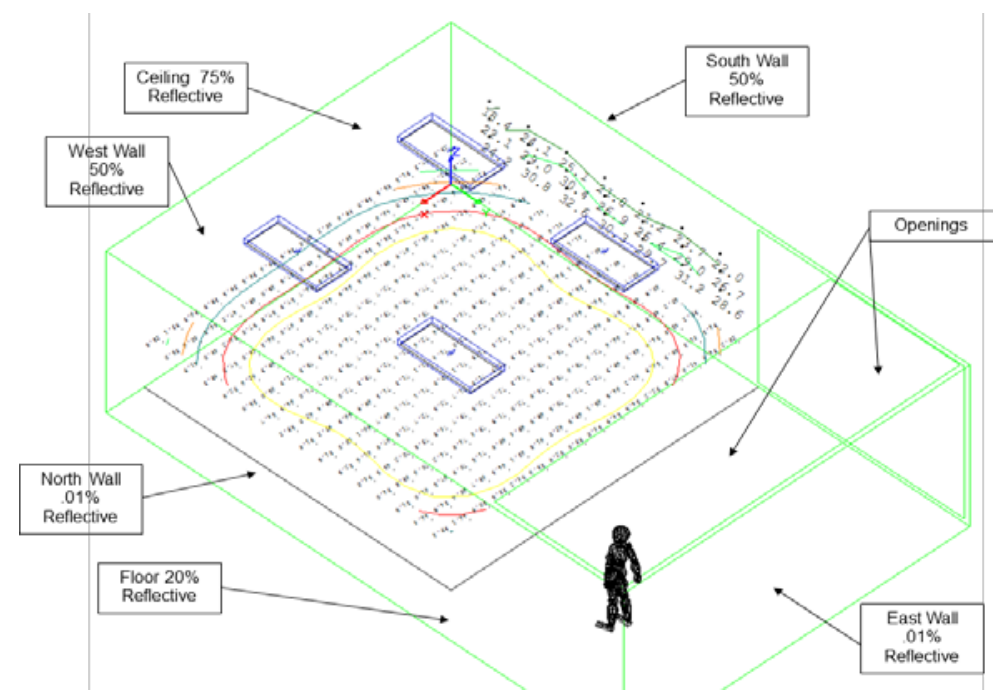

Figure 3.6. Aerial Depiction of Test Space 


\subsection{Results}

The GATEWAY Program evaluates the success of demonstrated products using the three criteria of (1) saving energy; (2) matching or improving the quality of illumination; and (3) offering costeffectiveness to the user relative to the product targeted for replacement. Any LED product that falls significantly short on any of these is generally not a viable candidate for widespread adoption by that user, though there may still be other valid reasons for implementation in specific instances.

Energy savings generally are easy to achieve when the other two criteria are not considered. However, energy savings often are accompanied by significant reductions in lumen output, and similar savings might be alternatively achieved by installing lower wattage conventional lamps and ballasts, or even by simply de-lamping the existing luminaires. This study focuses in particular on the second two criteria: quality of illumination and cost-effectiveness.

\subsection{Horizontal Illuminance}

Fluorescent troffers are most commonly (though not exclusively) used to provide ambient lighting in office settings. The measured illumination on a horizontal plane approximately 30 inches AFF corresponds to the light levels available on a desk or tabletop for reading and other office duties. A product's ability to sufficiently illuminate this horizontal plane is one critical gauge of its relative performance.

Figure 4.1 and Figure 4.2 show the horizontal results for both two- and three-lamp troffers that would typically be found in the current installed national inventory. Individual products in each fixture type align vertically by their measured wattage. The blue line is included for reference and corresponds to the average workplane footcandle per luminaire wattage ratio for all luminaires on the chart. Products above this line are performing better (i.e., delivering more footcandles per watt) than the average and products below, worse. ${ }^{6}$

\footnotetext{
${ }^{6}$ This line has no intrinsic meaning other than providing a frame of reference for gauging how a product compares with others on the chart. Both its slope and position would likely change as products are added or removed from the chart.
} 


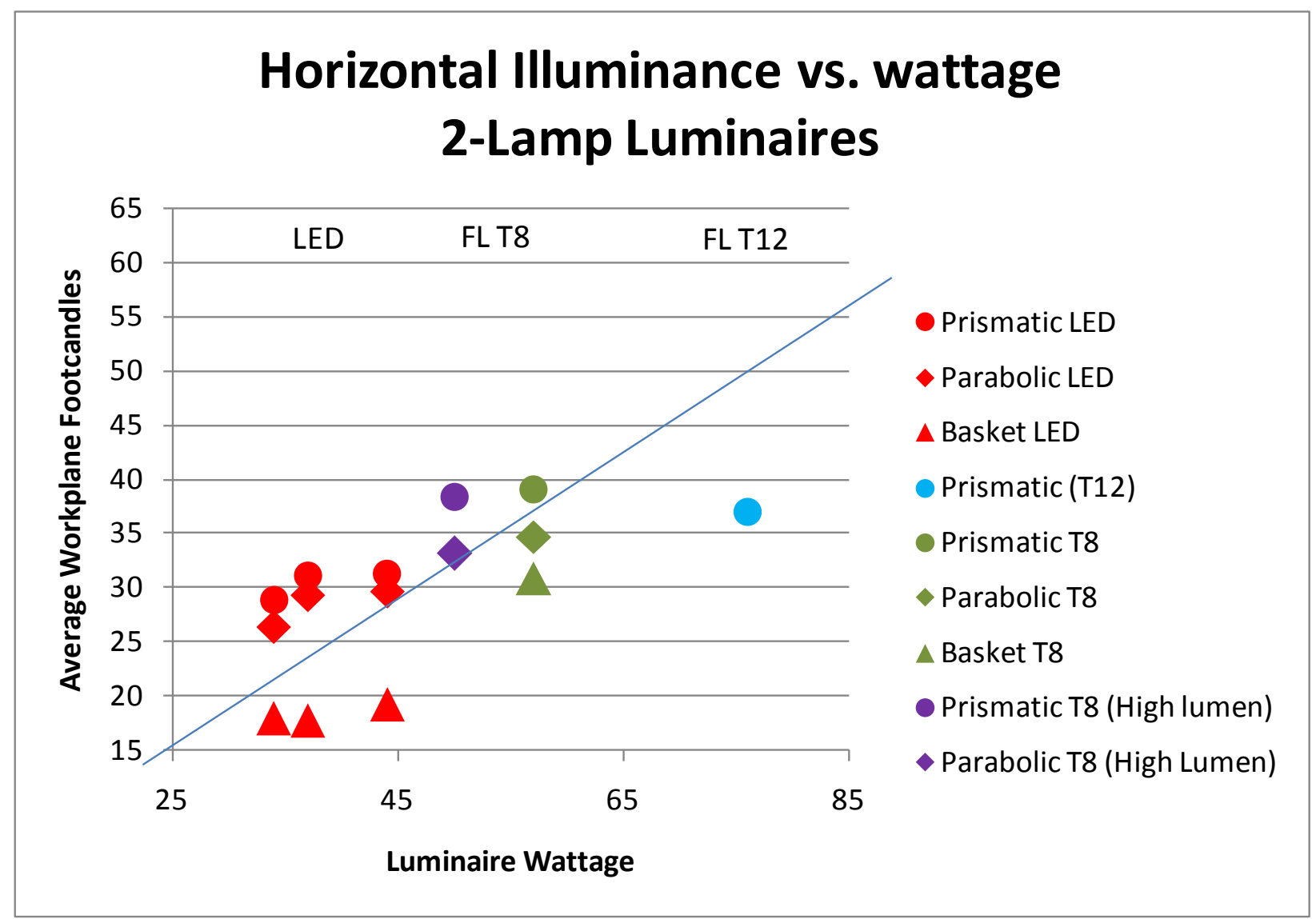

Figure 4.1. LED and Fluorescent Performance in Various Two-Lamp Fixtures, Horizontal Workplane 


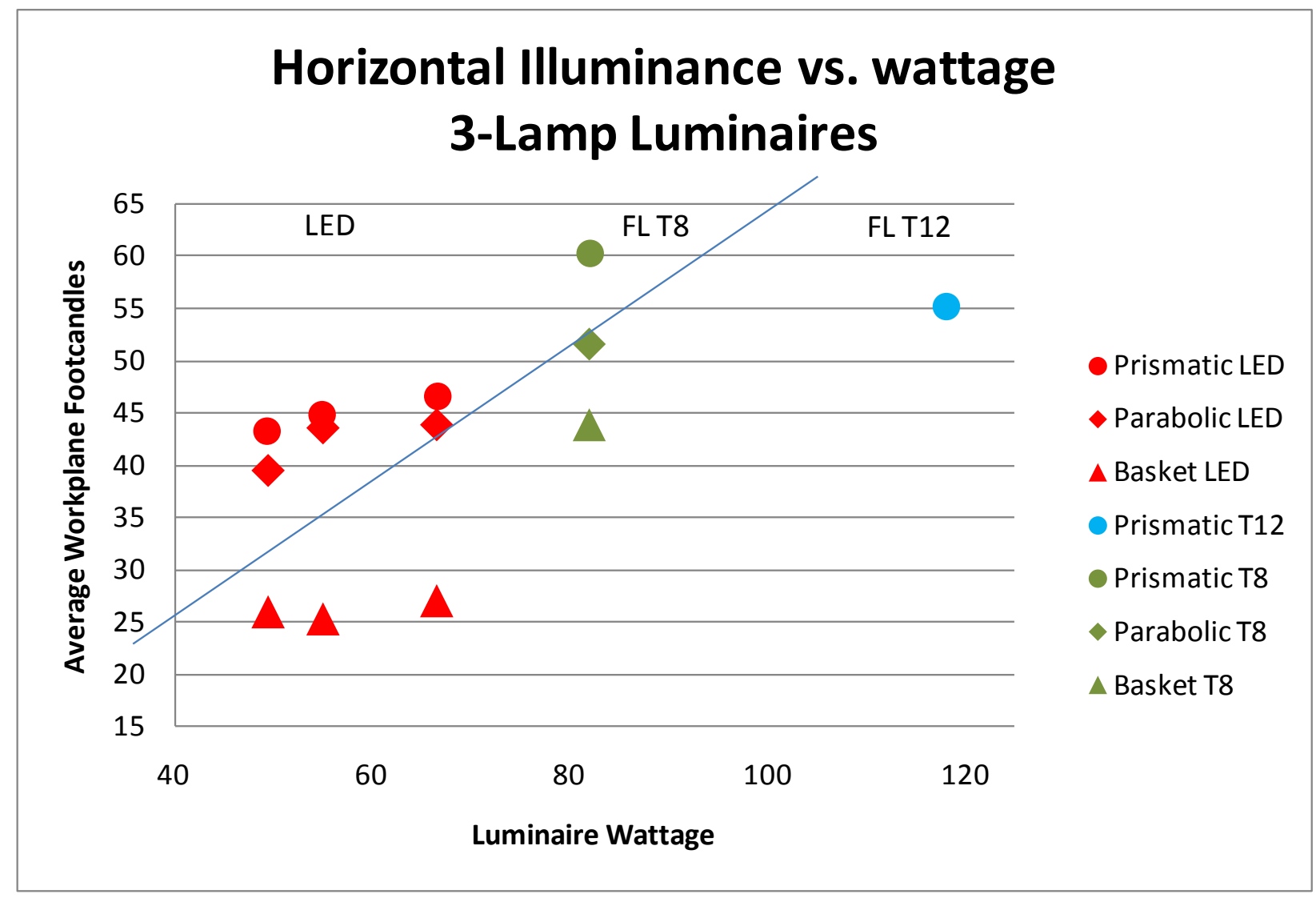

Figure 4.2. LED and Fluorescent Performance in Various Three-Lamp Fixtures, Horizontal Workplane

These figures reveal clear trends in comparative performance among the products tested. In all cases, the prismatic fixtures provide horizontal illuminance with relatively higher efficiency, whereas the basket-type fixtures demonstrate lower efficiency.

Although the fluorescent luminaires provide more average workplane illuminance than the replacement LED products in all cases, they also use more energy. In terms of delivered horizontal illumination per watt, these LED replacement products appear to be at or around par with the incumbent fluorescent products at least in prismatic lens and parabolic fixtures. However, the use of "average horizontal illumination" for comparison does not provide any information on the variability of the distribution on the lighted surface or illumination of any vertical surfaces or planes. For that, measures of uniformity and vertical illuminance must be examined. An industry accepted measure for lighting uniformity is the "average-to-minimum ratio" (avg-to-min) that relates the average measurement across the space to the minimum measurement in the space.

Figure 4.3 and Figure 4.4 present the calculated avg-to-min ratios for the test cases in both two-lamp and three-lamp configurations. Uniformity generally is improved with three-lamp configurations, while basket-type fixtures provide the best distribution capability (i.e., are the most uniform in both charts). It is also clear that while the ratios are not drastically different, the LED products generally show a wider variability in distribution uniformity. This is most likely due to the directional nature of LED replacement products and the fact that typical $2 \mathrm{ft}$ by $4 \mathrm{ft}$ luminaires are optically designed for omni- 
directional sources like linear fluorescent lamps. Only in the basket-type application did the LEDs consistently show the same or better uniformity than the fluorescent lamps. In other cases the uniformities of the LED systems were comparatively worse.

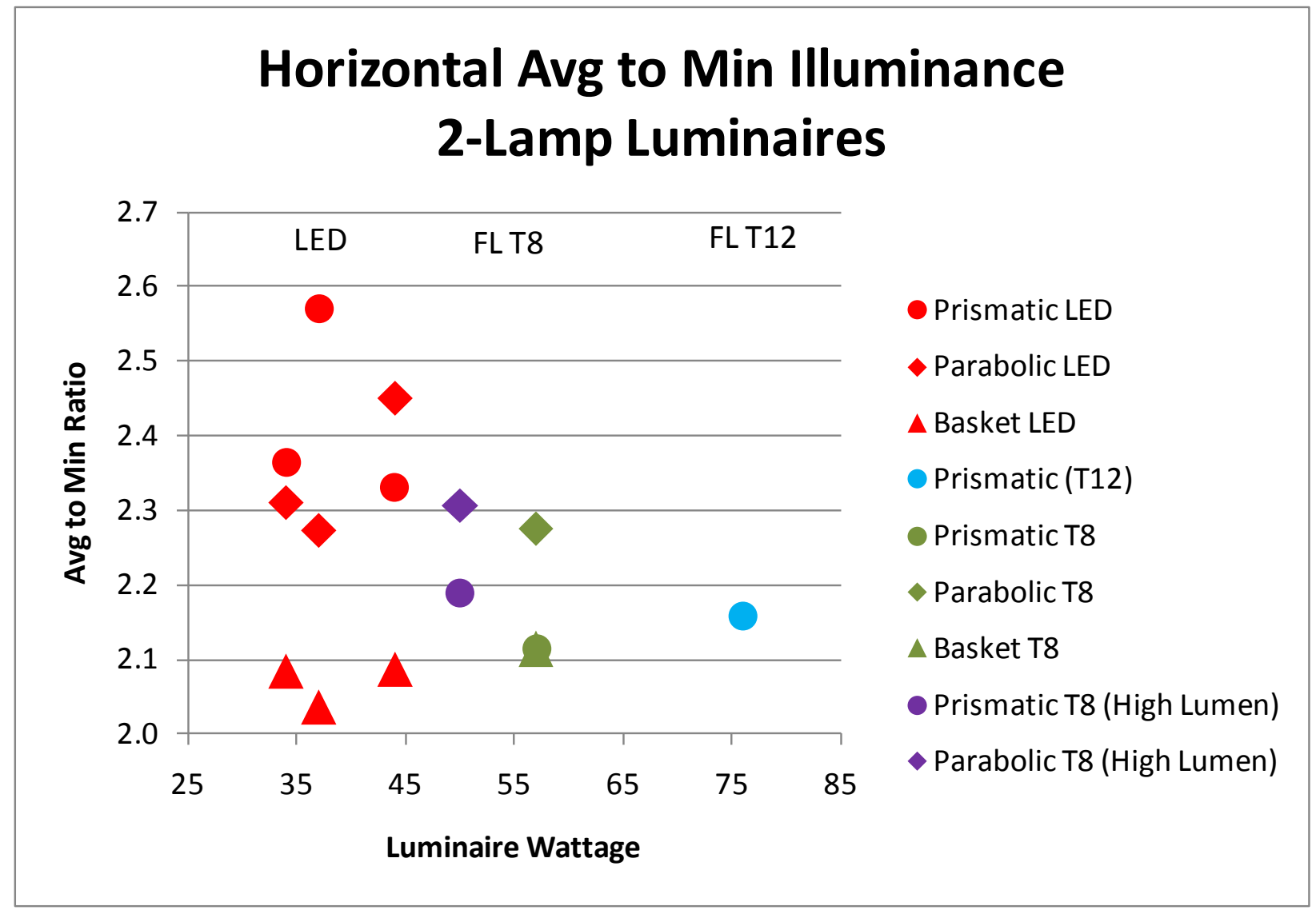

Figure 4.3. LED and Fluorescent Avg-to-Min Ratio for Various Two-Lamp Fixtures, Horizontal Workplane 


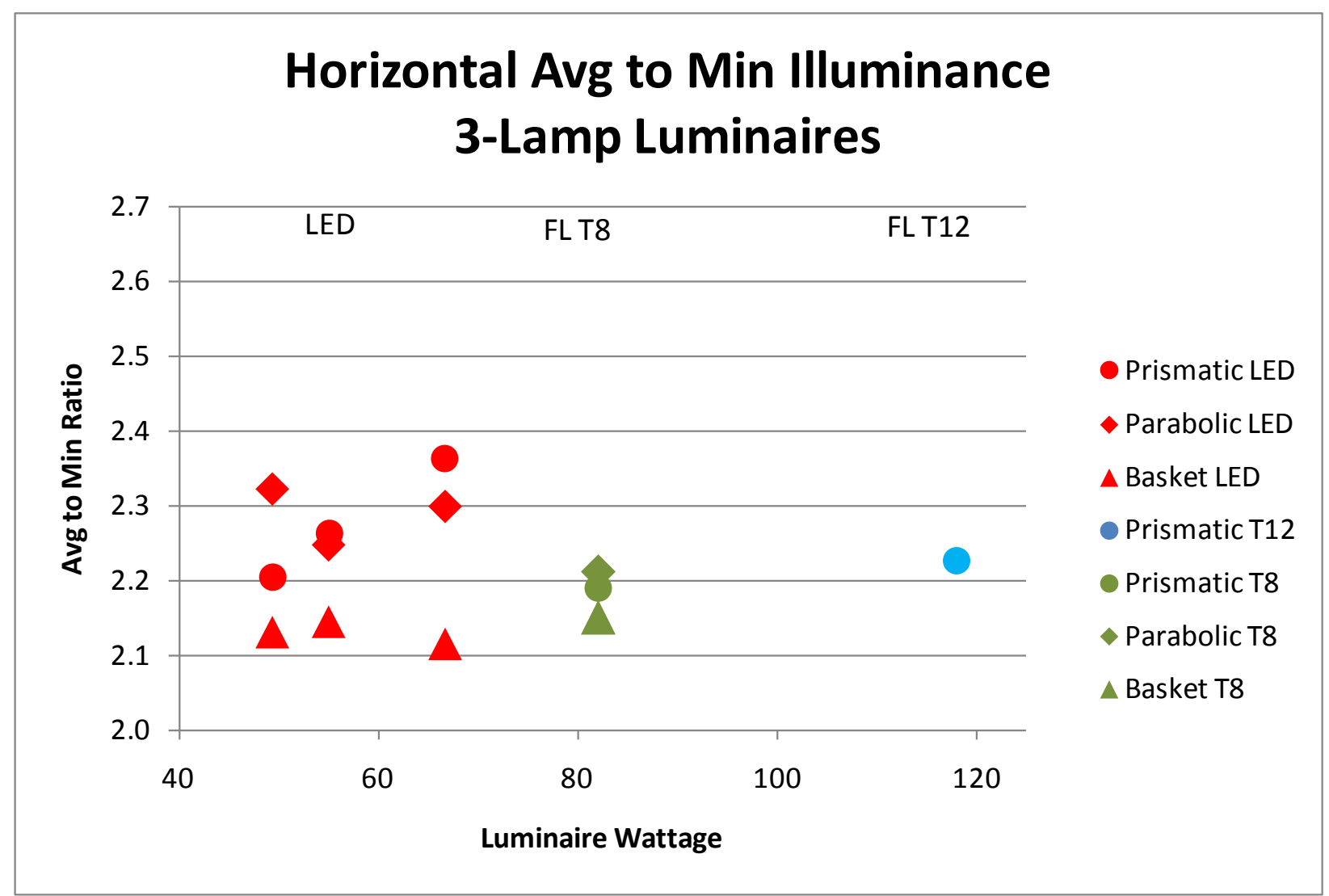

Figure 4.4. LED and Fluorescent Avg-to-Min Ratio for Various Three-Lamp Fixtures, Horizontal Workplane

\subsection{Vertical Illuminance}

The illumination of vertical surfaces in an office environment is important for reading the spines of books or files mounted in bookshelves, using chalkboards or dry-erase boards, viewing artwork or calendars hung from the wall, ease of facial recognition, and lending a natural appearance to the space. Vertical illumination also provides useful bounced light that improves illuminance uniformity, helping to mitigate shadows and make spaces appear more bright and cheerful. Luminaires failing to cast sufficient light on the walls of a room can impart a darkened, cave-like appearance, particularly if there are no exterior windows.

Figure 4.5 and Figure 4.6 show the relative vertical footcandles measured for each of the products evaluated in two- and three-lamp configurations. While drawing fewer watts than the fluorescent lamps, the LEDs do so at the expense of measured vertical illuminance. In terms of the normalized vertical footcandles per watt of luminaire power, the LEDs appear to be on par with the fluorescent performance. Matching the original vertical footcandle levels would require either higher wattage LED units or more of them (the latter no longer qualifying as a simple one-for-one replacement, however). 
Despite the drop in vertical illumination, the LEDs' measured values are still high enough to easily meet generic IES recommendations for most applications ${ }^{7}$ and nearly meet more specific derived lighting quality guidance ${ }^{8}$ (IES 2008).

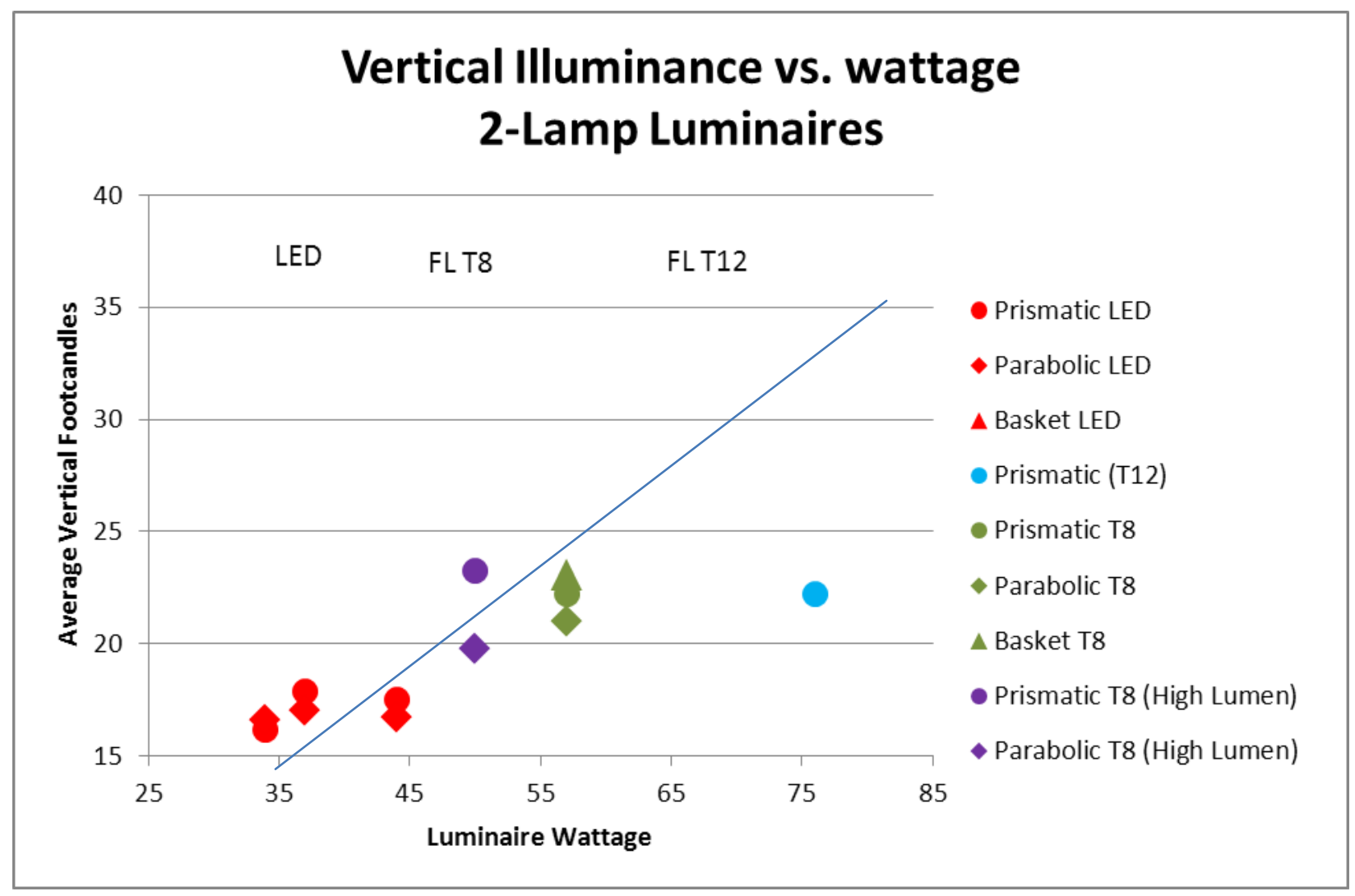

Figure 4.5. LED and Fluorescent Performance in Various Two-Lamp Fixtures, Vertical Plane

\footnotetext{
${ }^{7}$ The IESNA Lighting Handbook 9th Edition (IES 2000) recommends 5 vertical fc for typical open office environments. For filing, the handbook suggests $10 \mathrm{fc}$ and for chalkboards $50 \mathrm{fc}$. The handbook does not specify the height at which these values should be achieved. Vertical illuminance high on surrounding walls is considered important to room lighting quality, and this is not addressed with these recommendations.

${ }^{8}$ Light+Design: A Guide to Designing Quality Lighting for People and Buildings (IES DG-18-08, p 95) found in surveys that office workers showed a preference for a vertical illuminance level of about $30 \mathrm{candela} / \mathrm{m}^{2}$. Assuming a wall reflectance value of 0.7 translates this value into illuminance of about $15 \mathrm{fc}$.
} 


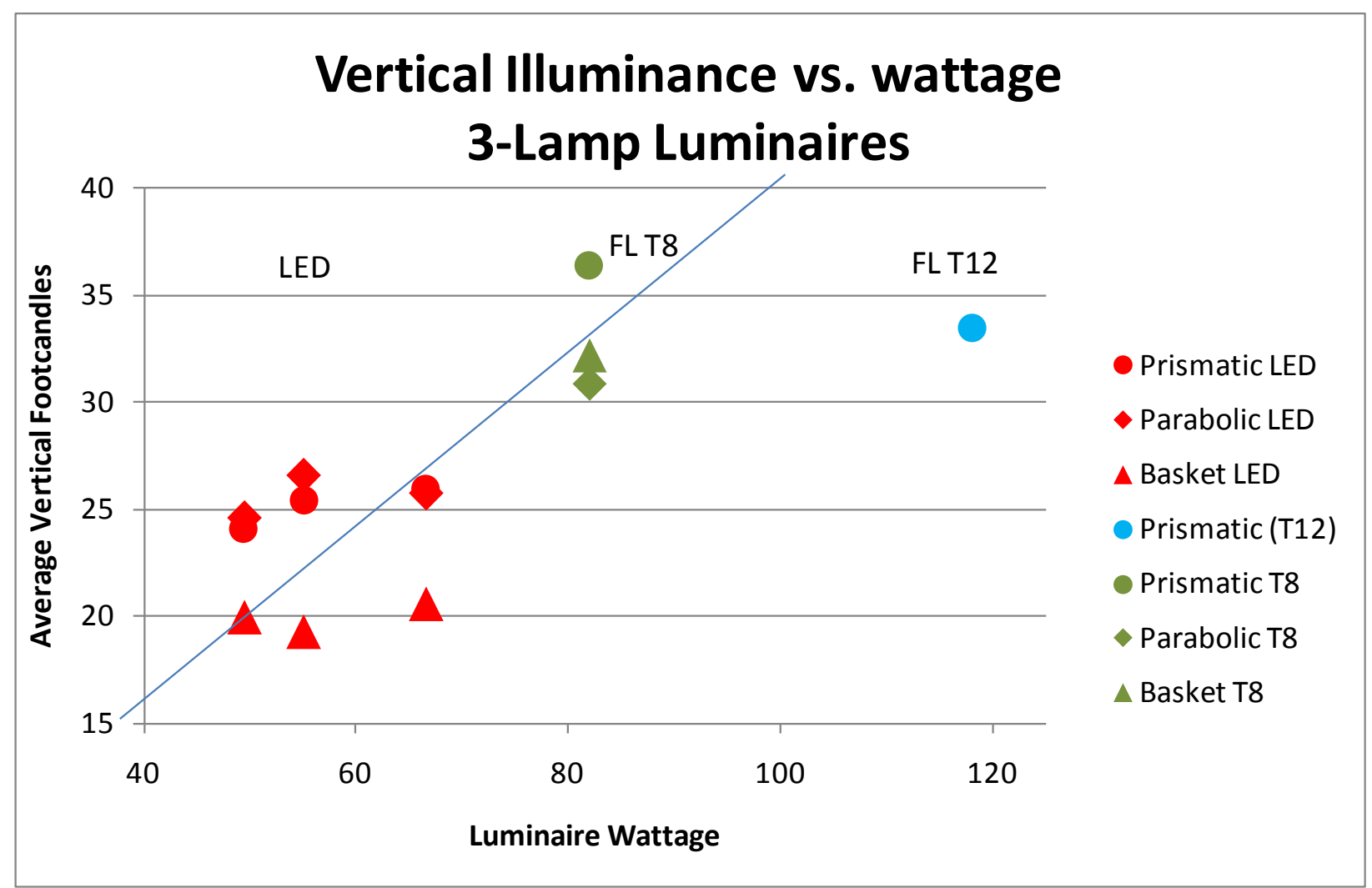

Figure 4.6. LED and Fluorescent Performance in Various Three-Lamp Fixtures, Vertical Plane

Vertical illuminance uniformity is also important for the quality of the lighted environment. Figure 4.7 and Figure 4.8 compare the vertical uniformity in terms of the avg-to-min ratio for all fixture and technology types. The results indicate that uniformity is similar between two-lamp and three-lamp configurations. The uniformity for prismatic and basket-type fixtures are also similar for both fluorescent and LED technologies. The one notable exception is in the parabolic fixture type, where the LED technology shows worse uniformity in both two- and three-lamp configurations. As with differences noted in horizontal uniformity, this effect is likely due to the directionality of LED products within a parabolic distribution system designed primarily for omni-directional sources. 


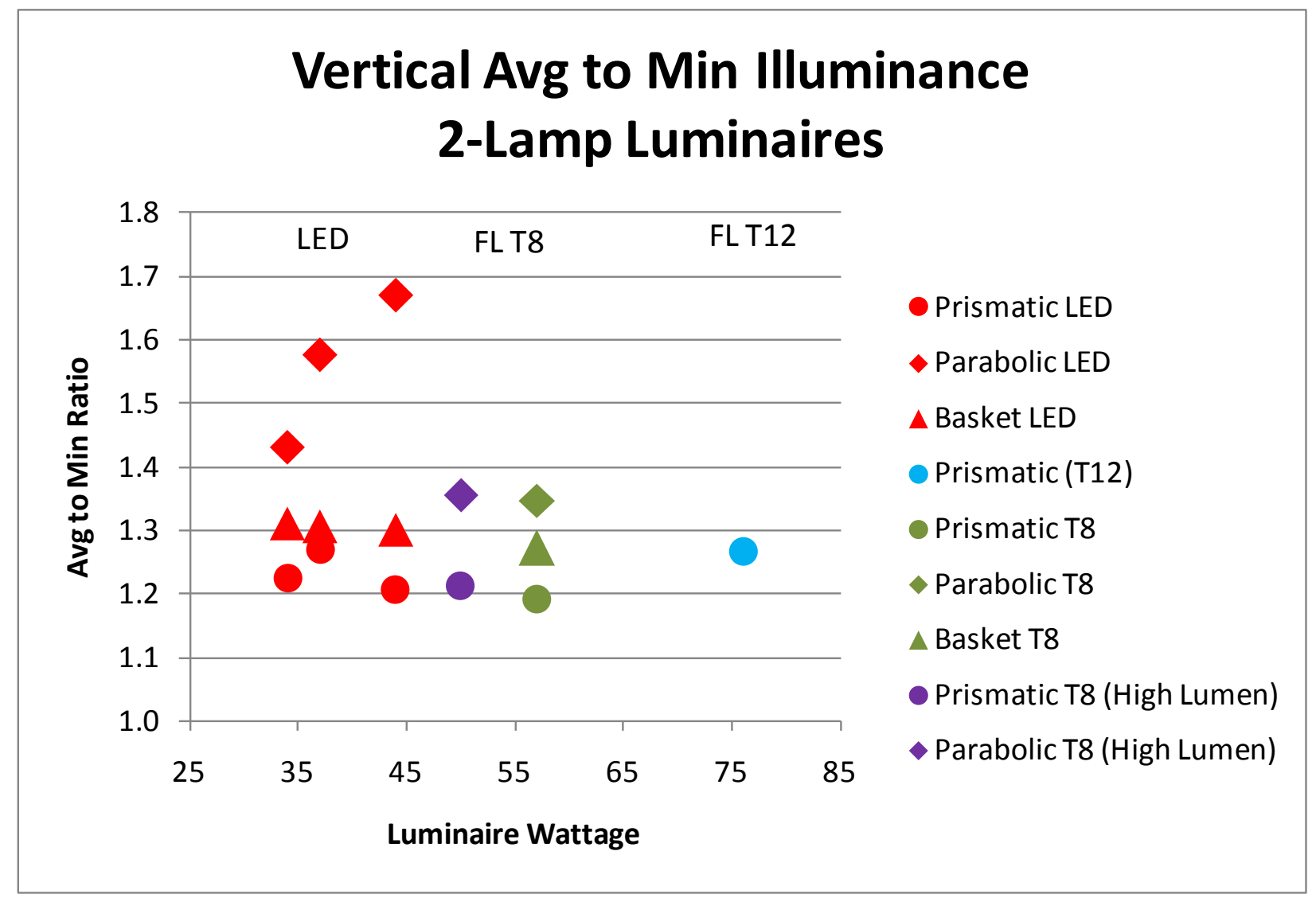

Figure 4.7. LED and Fluorescent Avg-to-Min Ratio for Various Two-Lamp Fixtures, Vertical Plane. . 


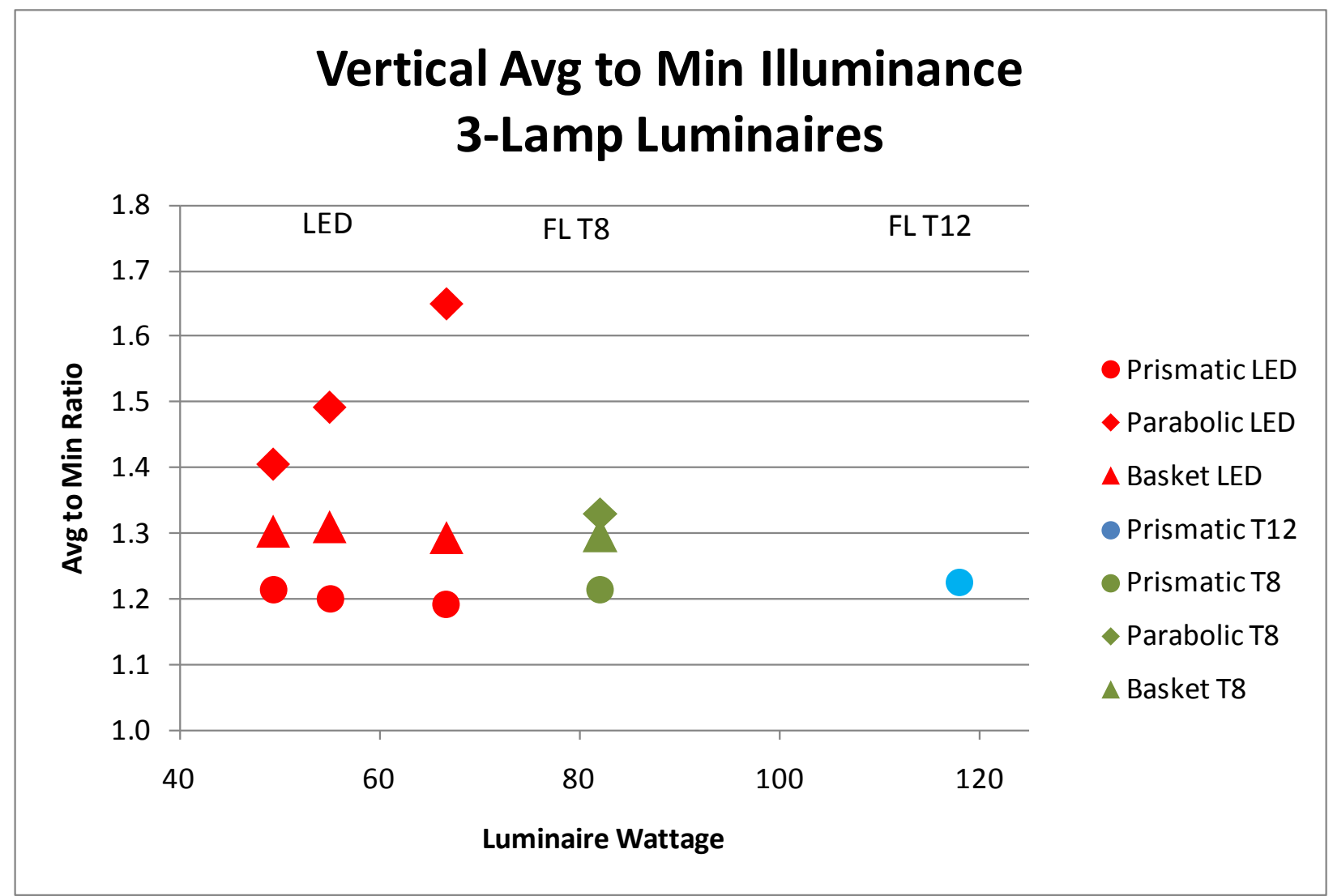

Figure 4.8. LED and Fluorescent Avg-to-Min Ratio for Various Three-Lamp Fixtures, Vertical Plane 


\subsection{Power Savings at Equivalent Light Output}

As stated, any lighting retrofit can produce energy savings from reduced lighting levels if the original levels were higher than needed. Although this may be an acceptable component of a retrofit, it complicates evaluation of the savings attributable specifically to a new technology and its associated costeffectiveness. Despite this complexity, however, it is necessary to distinguish between these two means of power reduction to get an accurate perspective on the new technology.

To provide insight for this part of the analysis, the test results were normalized to levels of illuminance equal to that of the standard T8 system. In other words, lumen output of LED replacement lamps was increased to theoretically provide the same workplane illuminance by proportionally increasing their corresponding wattage. The resulting percent differences in power draw to achieve these equal illuminance levels are compared and presented in Figure 5.1 and Figure 5.2.

The results here are mixed in terms of potential energy savings from LED replacements when equivalent horizontal illuminance levels are required (Figure 5.1). In basket-type fixtures, energy use of the LEDs compared to the standard T8 system would be increased by between 3 and 24 percent, while conversely, savings are achieved in lensed and parabolic fixture applications of between 3 and 23 percent. These are compared to high performance fluorescent T8 lamps, which provide corresponding savings of between 9 and10 percent across the board.

A similar look at vertical illuminance (Figure 5.2) shows that again LED replacement lamps in basket fixtures do not provide consistent energy savings (from 3 percent savings to 19 percent increase in energy use). In lensed and parabolic applications, the LED energy savings again range from 3-24 percent. In the same applications, fluorescent high performance T8 technology provides 7-16 percent savings relative to the standard T8 system. 


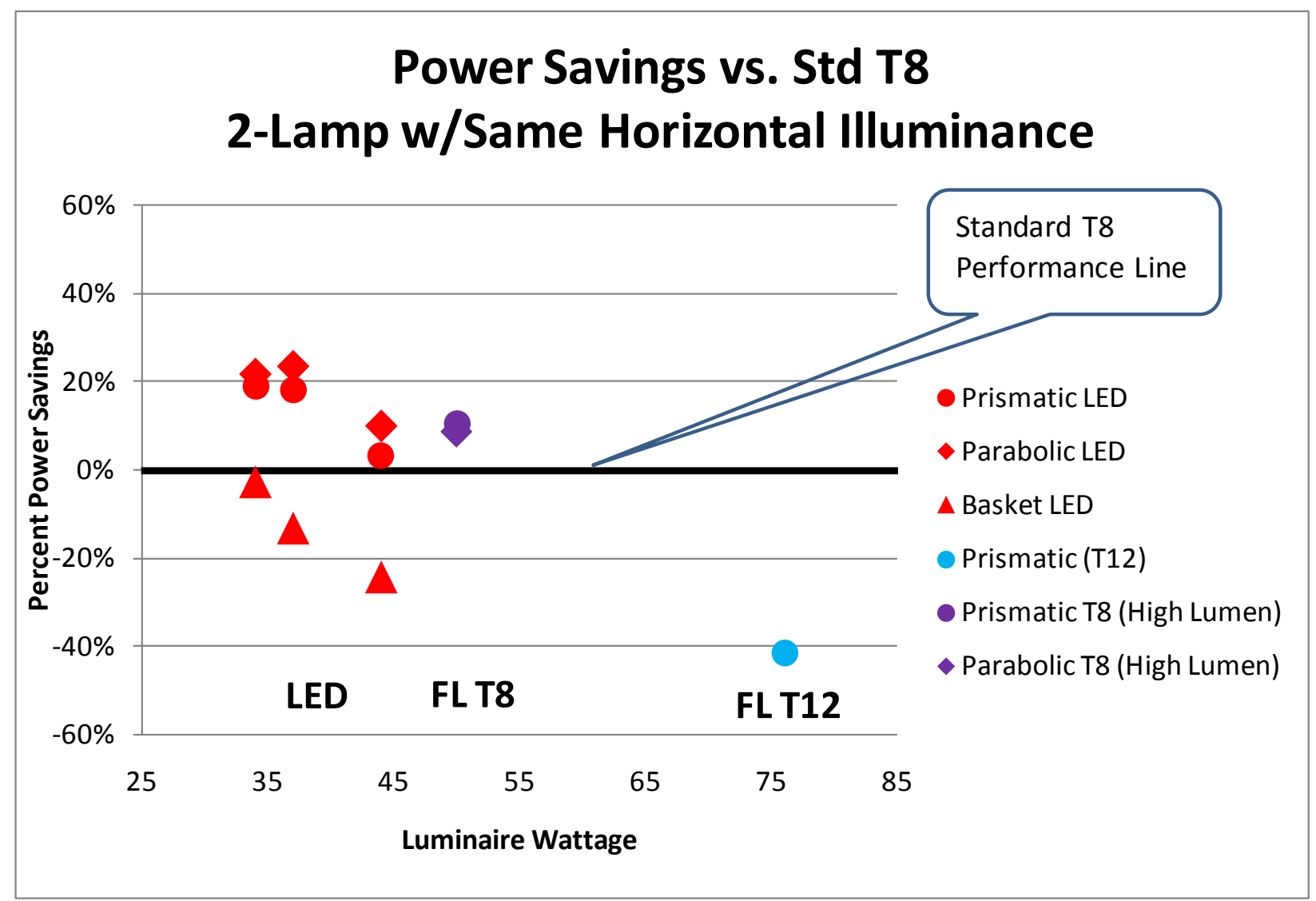

Figure 5.1. Percent Savings with Output Normalized to Standard FL T8, Horizontal Workplane 


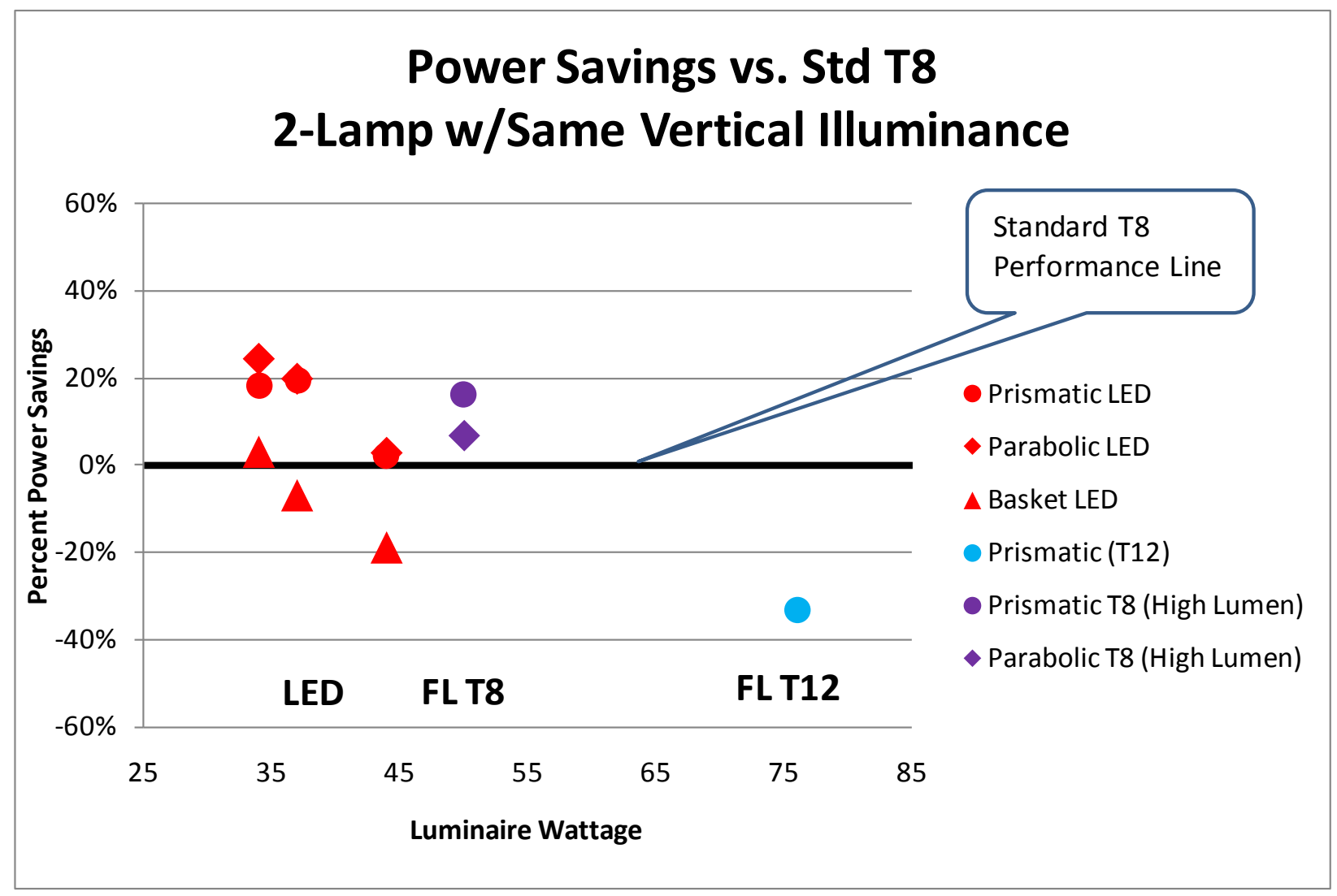

Figure 5.2. Percent Savings with Output Normalized to Standard FL T8, Vertical Plane 


\subsection{Cost Effectiveness}

Linear fluorescent lamp technology has been commercially available since the 1930s, and manufacturing methods for the important components were well established even before then. Linear fluorescent technology is fully mature, and even improved versions such as the high-lumen products tested in this study are relatively low cost. Performance, reliability, and lifetime of fluorescent products are extremely good. This combination provides strong competition for any new technology looking to displace linear fluorescent.

LED products, still being relatively new and undergoing considerable (albeit rapid) development, have a fair amount of remaining ground to cover before they will match fluorescent on a dollar-per-unit light output basis. Table 6.1 lists the purchase prices for all the products included in this study.

Table 6.1. Lamp Prices for Products Used in this Study

\begin{tabular}{lc}
\hline \multicolumn{1}{c}{ Product } & Price \\
\hline Fluorescent T8 (F32T8/735/ECO) lamp & $\$ 2.00^{* *}$ \\
Fluorescent T8 (high-lumen, F32T8/835/XPS/ECO) lamp & $\$ 4.55^{*}$ \\
Fluorescent T12 (F34T12/SS/ECO) lamp & $\$ 1.85^{*}$ \\
LED Product 01 & $\$ 89.69^{*}$ \\
LED Product 02 & $\$ 63.75^{*}$ \\
LED Product 03 & $\$ 120.00^{*}$ \\
Fluorescent T8 (25W/XL/XP) lamp & $\$ 5.50^{* * *}$ \\
\hline
\end{tabular}

* Per unit as delivered to Lighting Design Lab.

** Approximate, included in luminaire cost (delivered with fixture purchase).

*** Approximate, based on current distributor cost.

For all lamps (LED and fluorescent), lamp spot changing costs are estimated to be $\$ 7.68$ per twolamp fixture (27 minutes for a \$17.06/hour maintenance worker, including preparation and setup time, time to dispose of the lamps afterwards, etc. $)^{9}$. Additional costs for initial installation of the LED products come from the fact that all three products require disconnect/bypass of the existing fluorescent ballasts, a procedure that requires the services of a qualified electrician. The assumed one-time cost at the point of conversion is $\$ 29.67$ per troffer (30 minutes at an average pay rate of $\$ 59.33 /$ hour for an electrician and electrician's helper, including overhead and profit. Connecting these products to line voltage (nominal commercial voltage of 120 or 277 volts as delivered by the branch circuit) also creates potential safety issues down the road and may affect safety certifications; these issues and any associated costs are not further addressed in this study.

Economic performance of various products was compared using the Buildings Life-Cycle Cost tool (BLCC). ${ }^{10}$ In addition to first costs, the BLCC incorporates information on expected lifetime and replacement costs, including labor, discount rates, and escalation rates for materials and labor.

\footnotetext{
${ }^{9}$ Derived from (EERE 2009).

${ }^{10}$ The BLCC is a computer program developed by the National Institute of Standards and Technology to provide computational support for the analysis of capital investments in buildings.

http://www1.eere.energy.gov/femp/information/download_blcc.html
} 
In this set of comparisons, a 3 percent discount rate and 0 percent escalation were assumed. ${ }^{11}$ Annual period of operation was assumed to be 3000 hours for all products, with power costs of $\$ 0.11 / \mathrm{kWh}$. The period of analysis chosen was the lighting industry current default of one LED lifecycle, or 50,000 hours $^{12}$ (16.7 years at 3000 hours per year).

Table 6.2 breaks down the cost analysis results for the LED products and FL alternatives against the baseline of a standard T8 (735) lamp installation. Costs shown reflect use of two-lamp fixtures for a total eight lamps in the space. The Total Life-Cycle Cost column includes any residual value remaining for a given option at the end of the analysis period. Accounting for a residual value eliminates the issue of remaining lifetime of various options whose replacement periods are not precisely in sync with the analysis period. Table 6.3 presents similar analysis results for the same products and alternatives against a T12 baseline that is mostly obsolete but useful for comparison.

Table 6.2. Total Installation and Lifecycle Costs - T8(735) Baseline

\begin{tabular}{|c|c|c|c|c|c|c|}
\hline Product & $\begin{array}{c}\text { Total Lamp } \\
\text { Installation } \\
\text { Costs } \\
(\$ 2011)\end{array}$ & $\begin{array}{l}\text { Lifetime } \\
\text { (hrs) }\end{array}$ & $\begin{array}{l}\text { Life- } \\
\text { Cycle } \\
\text { Energy } \\
\text { Costs } \\
(\$ 2011)\end{array}$ & $\begin{array}{l}\text { Lifecycle } \\
\text { OM\&R } \\
\text { Costs* } \\
\text { (\$2011) }\end{array}$ & $\begin{array}{l}\text { Total Life- } \\
\text { Cycle Cost of } \\
\text { Alternative** } \\
\quad(\$ 2011)\end{array}$ & $\begin{array}{c}\text { Simple Payback } \\
\text { (years) }\end{array}$ \\
\hline $\begin{array}{l}\text { F32T8/735/ECO } \\
\text { with existing Instant } \\
\text { Start elec ballast }\end{array}$ & 32.00 & 25000 & 1030.00 & 37.00 & 1099.00 & Base case \\
\hline $\begin{array}{l}\text { LED01 Ballast } \\
\text { disconnected }\end{array}$ & 839.00 & 50000 & 679.00 & 0.00 & 1517.00 & Never reached \\
\hline $\begin{array}{l}\text { LED02 Ballast } \\
\text { disconnected }\end{array}$ & 629.00 & 50000 & 614.00 & 0.00 & 1243.00 & Never reached \\
\hline $\begin{array}{l}\text { LED03 Ballast } \\
\text { disconnected }\end{array}$ & 1079.00 & 50000 & 807.00 & 0.00 & 1886.00 & Never reached \\
\hline $\begin{array}{l}\text { F32T8/835/XPS } \\
\text { Change to LBF } \\
\text { Instant Start } \\
\text { premium ballast }\end{array}$ & 203.00 & 36000 & 904.00 & 47.00 & 1129.00 & 17 \\
\hline $\begin{array}{l}\text { F32T8/25W/XL/XP } \\
\text { SS with existing } \\
\text { Instant Start elec } \\
\text { ballast }\end{array}$ & 60.00 & 36000 & 813.00 & 37.00 & 898.00 & 2 \\
\hline
\end{tabular}

\footnotetext{
${ }^{11}$ A 3\% discount rate is normally used for governmental investments and thereby yields results that are conservative for the private sector. For example, a 6\% discount rate for the private sector can be derived using the methodology outlined at Damodaran Online (Damodaran 2011). A higher rate presents a greater hurdle for potential investments. A $0 \%$ escalation means that labor and materials increase at the same rate as inflation.

${ }^{12}$ Two of the three LED manufacturers reported "up to 50,000 hours...” The other did not report any value for lamp life, though 50,000 hours is commonly used in the industry.
} 
Table 6.3. Total Installation and Lifecycle Costs - T12 Baseline

\begin{tabular}{|c|c|c|c|c|c|c|}
\hline Product & $\begin{array}{c}\text { Total Lamp } \\
\text { Installation } \\
\text { Costs } \\
(\$ 2011) \\
\end{array}$ & $\begin{array}{l}\text { Lifetime } \\
\text { (hrs) }\end{array}$ & $\begin{array}{l}\text { Life- } \\
\text { Cycle } \\
\text { Energy } \\
\text { Costs } \\
(\$ 2011) \\
\end{array}$ & $\begin{array}{c}\text { Lifecycle } \\
\text { OM\&R } \\
\text { Costs* } \\
(\$ 2011) \\
\end{array}$ & $\begin{array}{l}\text { Total Life- } \\
\text { Cycle Cost of } \\
\text { Alternative** } \\
(\$ 2011)\end{array}$ & $\begin{array}{c}\text { Simple Payback } \\
\text { (years) }\end{array}$ \\
\hline $\begin{array}{l}\text { F34T12/SS/ECO } \\
\text { magnetic RS ballast. }\end{array}$ & 31.00 & 20000 & 1374.00 & 68.00 & 1458.00 & Base case \\
\hline $\begin{array}{l}\text { LED01 Ballast } \\
\text { disconnected }\end{array}$ & 839.00 & 50000 & 679.00 & 0.00 & 1517.00 & 14 \\
\hline $\begin{array}{l}\text { LED02 Ballast } \\
\text { disconnected }\end{array}$ & 629.00 & 50000 & 614.00 & 0.00 & 1243.00 & 10 \\
\hline $\begin{array}{l}\text { LED03 Ballast } \\
\text { disconnected }\end{array}$ & 1079.00 & 50000 & 807.00 & 0.00 & 1886.00 & Never reached \\
\hline $\begin{array}{l}\text { F32T8/735/ECO } \\
\text { Change to Instant } \\
\text { Start elec ballast }\end{array}$ & 183.00 & 25000 & 1030.00 & 37.00 & 1249.00 & 6 \\
\hline $\begin{array}{l}\text { F32T8/835/XPS } \\
\text { Change to LBF } \\
\text { Instant Start } \\
\text { premium ballast }\end{array}$ & 203.00 & 36000 & 904.00 & 47.00 & 1129.00 & 5 \\
\hline $\begin{array}{l}\text { F32T8/25W/XL/XP } \\
\text { SS Change to } \\
\text { Instant Start elec } \\
\text { ballast } \\
\text { *Includes replacements }\end{array}$ & 211.00 & 36000 & 813.00 & 52.00 & 1048.00 & 5 \\
\hline
\end{tabular}

In summary, none of the LED products tested is a more cost-effective alternative than modern fluorescent systems. Simple paybacks for the LEDs are either never reached (compared to common T8(735) system baseline) or are quite high (compared to the obsolete T12 system baseline). The FL alternatives offer lower life cycle cost and payback in comparison with both baselines. Furthermore, the LED products uniformly produced lower light levels than the tested fluorescent lamps, so the respective costs estimated above for the LED replacement options do not even reflect similar levels of illuminance compared to the baselines. In addition, the comparison thus far is based on initial rather than maintained lumens. If the LED products are to be left in place for the expected lifetime, their lumen output is assumed to decrease to 70 percent of initial lumens (the usual definition of LED useful life is $70 \%$ of initial light output), further reducing illumination levels relative to the high-performance fluorescent lamps, which by comparison are typically expected to fade down to 90 percent of initial lumens before failing (some retain as high as 97 percent before failing). ${ }^{13}$ Figure 5.1 presents a model of what a typical installation may experience with various products like those tested in this analysis. The curves shown are based on industry stated life values for FL products and the noted 50,000 hour life for LEDs that is typically associated with a lumen output value of 70 percent of initial output. The typical approach to accommodating anticipated lumen depreciation is to over-design the light levels at the outset in proportion to the expected lumen decrease over the system’s life.

\footnotetext{
${ }^{13}$ Lumen depreciation for standard T8/735 and T12 lamps is greater than for the high-performance fluorescent lamps, but is less relevant due to their coming phaseout.
} 


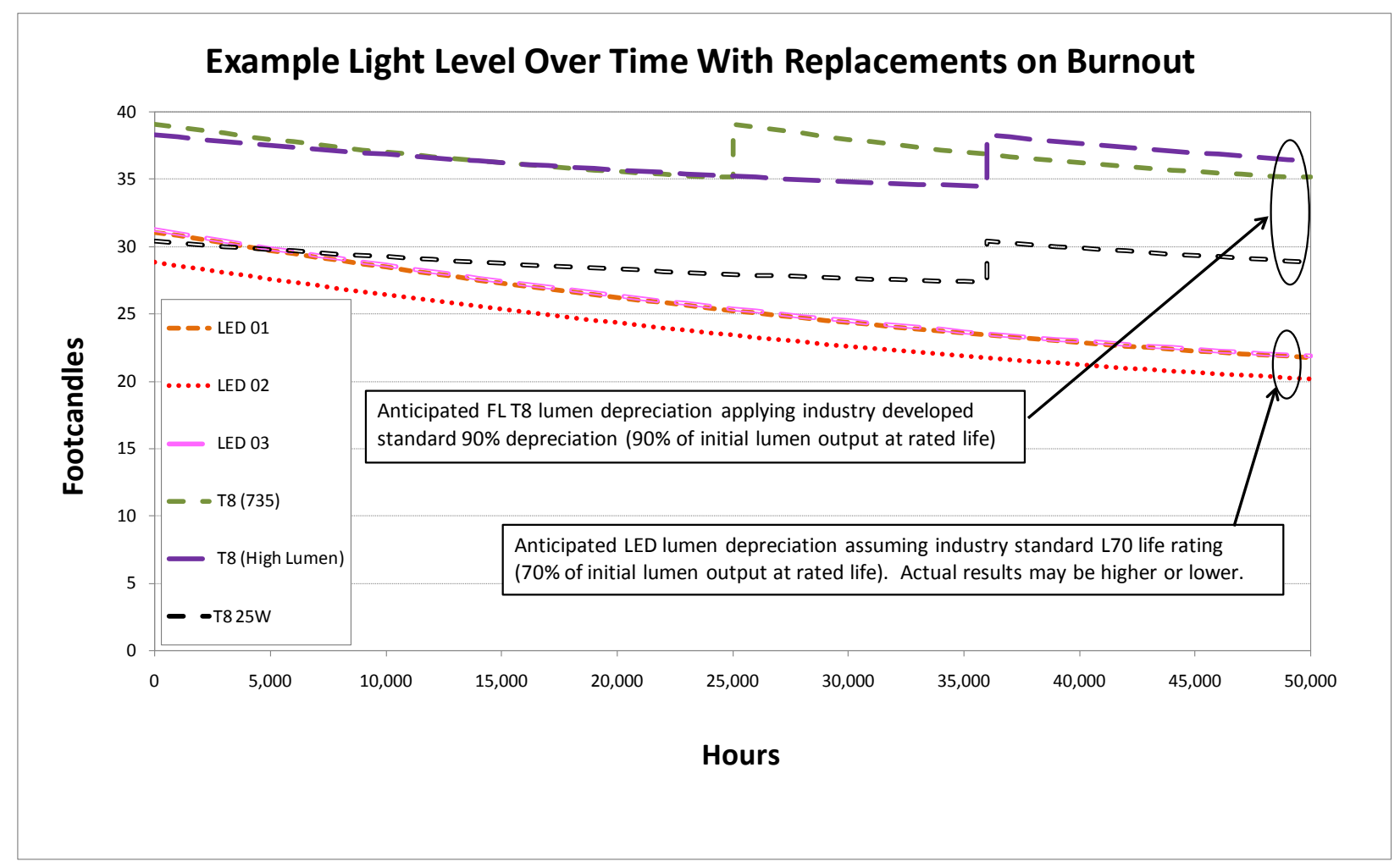

Figure 6.1. Light Level Reduction Over Time Including Lamp Replacement on Failure

The bottom line is that if the existing illumination levels are to be maintained, switching to any of these LED products means either using significantly more of them (with correspondingly higher costs and energy use) or supplementing them with task lighting or other additional sources of light. As a one-forone replacement alternative, the tested LED products do not satisfy either GATEWAY requirement of matching or improving the quality of illumination, or of being cost effective relative to the incumbent technology.

Conversely, if the space is currently over-lighted, then other options might also be considered such as substituting lower wattage fluorescent lamps or lower ballast factor ballasts. The last row of Table 6.2 is included to illustrate this point by providing a standard alternative option based on equivalent illumination levels. This 25W T8 fluorescent product was not tested in the study, but was instead identified using manufacturer photometric data as being likely to produce initial illuminance levels similar to the LED products. This product can be readily obtained from electrical distributors for around $\$ 5.50$ or less in case quantities, and is a valid alternative compared to any of the tested LED products if reduced light levels in the space are acceptable. An additional advantage of this option is that it can be applied without altering the existing T8 fluorescent instant start ballasts. Going to such a lower wattage fluorescent achieves overall energy savings on par with the LED products with similar reduced light levels at the lowest cost of all options examined in the table. ${ }^{14}$ In addition, per the discussion above, maintained light levels from this option will be well above those of the LEDs by the time the LEDs reach their end of life.

\footnotetext{
${ }^{14}$ An even lower cost possibility might be to simply “de-lamp” existing troffers, e.g., removing one lamp from every other fixture, if lower illumination and other aesthetic impacts are acceptable. This approach is nearly costfree.
} 


\subsection{Conclusion}

LED products for general illumination applications are becoming increasingly available and can be found for most applications desired. A primary marketing point for these products is energy savings. Although many of these products do use less electricity than the incumbent products they are claimed to replace, electricity savings is only one aspect of an effective application and should not be used in isolation to justify a products' implementation without careful consideration of the other factors.

In this study, the LED products did provide slightly more effective light delivery (footcandle per watt of power) for prismatic lensed and parabolic luminaires, but provided less effective delivery in baskettype luminaires. In all cases, the LED products produced lower illuminance readings on the horizontal and vertical planes. Thus, a significant amount of the energy savings achieved by these LEDs was due to lower illuminance rather than superior performance. However, the fact that LEDs, still a relative newcomer in the general illumination arena, can compete with a longstanding technology at all speaks to their high level of (and still rapidly improving) performance.

Buyers of any LED-based product must fully understand the needs of their specific application and the characteristics of the LED product(s) under consideration, to confirm that the product(s) will deliver the necessary performance. The three LED products evaluated in this study represent the upper range of performance of products in this application category at the time the study was conducted. Their performance, as measured against typical linear fluorescent products commonly found in office and other lighting applications, was found to be just barely within the range of what could be considered “equivalent” when new, and no longer equivalent by their end of life. However, as new products are continually being introduced to the market, it is probable that others will eventually exceed the performance of the products tested here with correspondingly improved results.

Cost of the LED products continues to be the primary remaining hurdle preventing their widespread suitability for this application. The LED products evaluated in this study averaged between 15 and 60 times the per-unit costs of the fluorescent products obtained. Such a premium continues to present a challenge to economically justifying the purchase of LED T8 replacement products in most situations given that their performance is at best comparable to the incumbent fluorescents. Certainly lower cost and lower-wattage LED products are already abundantly available on the market, but if their performance is also lower, they are unlikely to be effective replacement options.

Each product purchase should always be considered on its own specific cost and performance benefits against the lighting needs of the space. Consumers should evaluate the potential light output of any replacement option under consideration. At a minimum, the initial light output ratings of potential products should be compared to determine the potential for achieving equivalent light levels if that is a desired result. In addition, calculated or estimated energy savings should always be compared to retrofit costs to determine the cost-effectiveness of the project. 


\subsection{References}

Damodaran - Damodaran Online. 2011. Costs of Capital by Industry Sector. Accessed May 11, 2011 at http://www.stern.nyu.edu/ adamodar/pc/datasets/wacc.xls.

EERE - U.S. Department of Energy, Office of Energy Efficiency and Renewable Energy. 2009. Final Rule Technical Support Document (TSD): Energy Conservation Standards for General Service Fluorescent Lamps and Incandescent Reflector Lamps. Chapter 8, Life-Cycle Cost and Payback Period Analysis. July 2009. Washington, DC.

http://www1.eere.energy.gov/buildings/appliance standards/residential/pdfs/ch 8 lamps standards final tsd.pdf

EIA - U.S. Department of Energy, Energy Information Administration. 2008. Commercial Buildings

Energy Consumption Survey (CBECS), Table E5A. Accessed April, 2011 at

http://www.eia.doe.gov/emeu/cbecs/ (undated webpage).

IES - Illuminating Engineering Society of North America. 2000. IESNA Lighting Handbook, $9^{\text {th }}$ Edition. July 200. New York.

IES - Illuminating Engineering Society of North America. 2008. Light+Design: A Guide to Designing Quality Lighting for People and Buildings, DG-18-08, p 95. November 2008. New York.

Navigant - Navigant Consulting, Inc. 2010. Energy Savings Potential of Solid-State Lighting in General Illumination Applications 2010 to 2030. February 2010. Washington, D.C. 


\section{Appendix A: Collected Data}





\section{Appendix A}

\section{Collected Data}

\begin{tabular}{|c|c|c|c|c|c|c|c|c|c|c|}
\hline \multicolumn{11}{|c|}{ Horizontal Grid Data } \\
\hline & \multicolumn{2}{|c|}{ Fixture Type >> } & \multicolumn{2}{|c|}{ Prismatic } & \multicolumn{2}{|c|}{ Parabolic } & \multicolumn{2}{|c|}{ Basket } & \multicolumn{2}{|c|}{$\begin{array}{c}\text { HP } \\
\text { Lensed(RT8) } \\
\end{array}$} \\
\hline $\begin{array}{c}\text { Lamp } \\
\text { Quantity }\end{array}$ & Lamp Type & \begin{tabular}{|c|}
$\begin{array}{c}\text { System } \\
\text { Watts }\end{array}$ \\
\end{tabular} & $\begin{array}{l}\text { Avg } \\
\text { Horiz fc }\end{array}$ & $\begin{array}{l}\text { Avg to } \\
\text { Min }\end{array}$ & \begin{tabular}{|l|} 
Avg \\
Horiz fc
\end{tabular} & \begin{tabular}{|l|} 
Avg to \\
Min
\end{tabular} & $\begin{array}{l}\text { Avg } \\
\text { Horiz fc }\end{array}$ & \begin{tabular}{|l|} 
Avg to \\
Min
\end{tabular} & \begin{tabular}{|l|} 
Avg \\
Horiz fc
\end{tabular} & \begin{tabular}{|l|} 
Avg to \\
Min
\end{tabular} \\
\hline 2 & LED 01 & 37.0 & 31.1 & 2.57 & 29.3 & 2.27 & 17.7 & 2.04 & & \\
\hline 2 & LED 02 & 34.0 & 28.9 & 2.36 & 26.3 & 2.31 & 17.9 & 2.08 & & \\
\hline 2 & LED 03 & 44.0 & 31.2 & 2.33 & 29.7 & 2.45 & 19.2 & 2.09 & & \\
\hline 2 & T12 & 76.0 & 36.9 & 2.16 & & & & & & \\
\hline 2 & T8 (735) & 57.0 & 39.1 & 2.11 & 34.6 & 2.28 & 30.9 & 2.11 & 40.0 & 2.22 \\
\hline 2 & T8 (hi-lumen) & 50.0 & 38.3 & 2.19 & 33.2 & 2.31 & & & & \\
\hline & & & & & & & & & & \\
\hline 3 & LED 01 & 55.0 & 44.8 & 2.26 & 43.6 & 2.25 & 25.3 & 2.15 & & \\
\hline 3 & LED 02 & 49.4 & 43.2 & 2.21 & 39.5 & 2.32 & 26.0 & 2.13 & & \\
\hline 3 & LED 03 & 66.6 & 46.6 & 2.36 & 43.9 & 2.30 & 27.1 & 2.12 & & \\
\hline 3 & T12 CW34 & 118.0 & 55.2 & 2.23 & & & & & & \\
\hline 3 & T8 (735) & 82.0 & 60.3 & 2.19 & 51.5 & 2.21 & 43.9 & 2.15 & & \\
\hline
\end{tabular}

\begin{tabular}{|c|c|c|c|c|c|c|c|c|c|c|}
\hline \multicolumn{11}{|c|}{ Vertical Grid Data } \\
\hline & \multicolumn{2}{|c|}{ Fixture Type $\gg$} & \multicolumn{2}{|c|}{ Prismatic } & \multicolumn{2}{|c|}{ Parabolic } & \multicolumn{2}{|c|}{ Basket } & \multicolumn{2}{|c|}{\begin{tabular}{|c|}
$\mathrm{HP}$ \\
Lensed(RT8) \\
\end{tabular}} \\
\hline $\begin{array}{l}\text { Lamp } \\
\text { Quantity }\end{array}$ & $\begin{array}{l}\text { Lamp } \\
\text { Type }\end{array}$ & $\begin{array}{c}\text { System } \\
\text { Watts }\end{array}$ & $\begin{array}{l}\text { Avg } \\
\text { Vert fc }\end{array}$ & $\begin{array}{l}\text { Avg } \\
\text { to Min }\end{array}$ & $\begin{array}{l}\text { Avg } \\
\text { Vert } \\
\text { fc }\end{array}$ & $\begin{array}{l}\text { Avg } \\
\text { to Min }\end{array}$ & $\begin{array}{l}\text { Avg } \\
\text { Vert } \\
\text { fc }\end{array}$ & $\begin{array}{l}\text { Avg } \\
\text { to } \\
\text { Min }\end{array}$ & $\begin{array}{l}\text { Avg } \\
\text { Vert } \\
\text { fc }\end{array}$ & \begin{tabular}{|l|} 
Avg \\
to \\
Min
\end{tabular} \\
\hline 2 & LED 01 & 37.0 & \begin{tabular}{|l|}
17.9 \\
\end{tabular} & 1.27 & 17.0 & 1.58 & 14.0 & 1.31 & & \\
\hline 2 & LED 02 & 34.0 & 16.2 & 1.22 & 16.6 & 1.43 & 14.2 & 1.31 & & \\
\hline 2 & LED 03 & 44.0 & 17.5 & 1.21 & 16.7 & 1.67 & 15.0 & 1.30 & & \\
\hline 2 & T12 & 76.0 & 22.2 & 1.27 & & & & & & \\
\hline 2 & T8 (735) & 57.0 & 22.2 & 1.19 & 21.0 & 1.35 & 23.0 & 1.27 & 26.2 & 1.22 \\
\hline 2 & $\begin{array}{c}\text { T8 (hi- } \\
\text { lumen) }\end{array}$ & 50.0 & 23.3 & 1.21 & 19.8 & 1.36 & & & & \\
\hline 3 & LED 01 & 55.0 & 25.4 & 1.20 & 26.6 & 1.49 & 19.3 & 1.31 & & \\
\hline 3 & LED 02 & 49.4 & 24.1 & 1.22 & 24.6 & 1.41 & 19.9 & 1.30 & & \\
\hline 3 & LED 03 & 66.6 & 26.0 & 1.19 & 25.7 & 1.65 & 20.6 & 1.29 & & \\
\hline 3 & \begin{tabular}{|l|} 
T12 \\
CW34
\end{tabular} & 118.0 & 33.4 & 1.22 & & & & & & \\
\hline 3 & T8 (735) & 82.0 & 36.4 & 1.21 & 30.8 & 1.33 & 32.2 & 1.30 & & \\
\hline
\end{tabular}




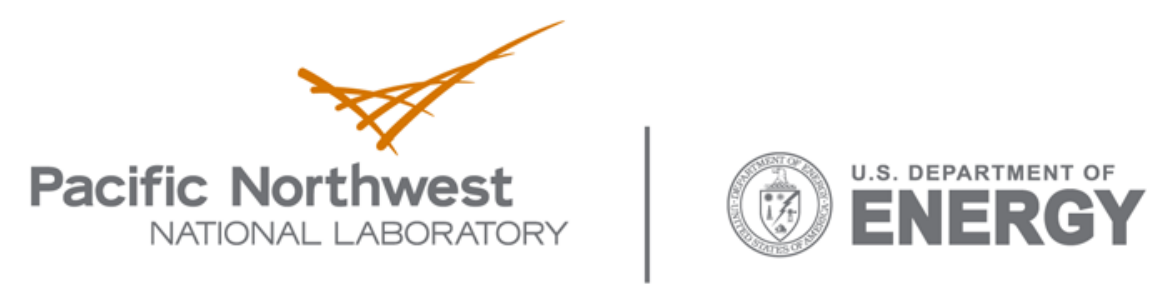

902 Battelle Boulevard

P.O. Box 999

Richland, WA 99352

1-888-375-PNNL (7665)

www.pnl.gov 